\title{
Arşivcinin Efemerası
}

\section{Ephemera from an Archivist's Perspective}

\author{
İshak Keskin ${ }^{1}$
}

' (Prof. Dr.) İstanbul Üniversitesi, Edebiyat Fakültesi, Bilgi ve Belge Yönetimi Bölümü, İstanbul, Türkiye

ORCID: İ.K. 0000-0003-1611-1330

Sorumlu yazar/Corresponding author: İshak Keskin,

İstanbul Üniversitesi, Edebiyat Fakültesi, Bilgi ve Belge Yönetimi Bölümü, İstanbul, Türkiye E-posta: ishak.keskin@istanbul.edu.tr

Başvuru/Submitted: 04.05.2021

Revizyon Talebi/Revision Requested: 07.05.2021 Kabul/Accepted: 23.05.2021

Online Yayın/Published Online: 25.06.2021

Atıf/Citation: Keskin, İ. (2021). Arşivcinin efemerası. Bilgi ve Belge Araştırmaları Dergisi, $15,1-32$.

http://doi.org/10.26650/bba.2021.15.01
ÖZ

Efemera, farklı tür ve içeriğe sahip materyale verilen genel bir isimlendirmedir. Okul diplomaları, faturalar, karneler, otobüs, sinema ve piyango biletleri, spor toto ve spor loto kuponları, gazete nüshaları, tanıtım broşürleri, mektuplar, lokanta mönüleri, tapu ve noter senetleri, banka dekontları, çikolata ve sakızlardan çıkan kartlar, sigara kutuları, posterler, pasaportlar, fotoğraflar, kartpostallar, düğün davetiyeleri, kartvizitler bu belge örneklerinden bazılarıdır. Bunlar; günümüz kültür tarihi çalışmalarında kullanılan önemli belgeler arasındadır. Ancak üretildiği organizasyon, üretim malzemesi, üretim adedi, dosya bağından yoksun olması gibi birtakım özellikler efemeranın tanımlanmasını güçleştirir. Bunun bir sonucu olarak arşivci, efemerayı kurumsal/kişisel nitelikli ve kurumların/kişilerin faaliyetleri sonucunda üretilen ve işlemler sonucunda gelen arşiv kayıtları arasında görmez. Çalışmada, efemera türü belgeler hakkında bilinen tanımlardan ve literatürde geçen efemera türlerinden yola çıkılarak efemeranın özellikleri, kaynak değeri ve özellikle de bir arşivcinin efemerayı nasıl değerlendirdiği sorularına cevap aranmıştır. Araştırmada nitel araştırma yönteminden ve durum çalışmasından yararlanılmış olup, verilerin analizi için doküman analizi tekniğine başvurulmuştur.

Anahtar kelimeler: Efemera, arşivci, belgelendirme stratejisi, tarihi kaynaklar, tarih araştırmaları

\section{ABSTRACT}

Ephemera, a generalized term for a variety of items originally intended for short-term use, can include the following: bank receipts, bills, bus, cinema and lottery tickets, business cards, chocolate and gum cards, cigarette boxes, deeds and other notarized documents, letters, newspaper copies, passports, photographs, pool coupons, postcards, posters, promotional brochures, restaurant menus, report cards, school diplomas, and wedding invitations. Such documents are used in today's cultural history studies. However, difficulty in identifying ephemera comes from their features, for instance, the producing organization, production material, production number, and/or lack of a file link. Consequently, archivists do not see ephemera among institutional/personal archival records or those produced from actions/ transactions. Based on the literature's definitions of ephemera documents and species, this study discusses questions of ephemera's properties, source value, and methods of archivist evaluation. The study used a qualitative research method and, for data analysis, a document analysis technique.

Keywords: Ephemera, archivist, documentation strategy, historical resource, historical research 


\section{EXTENDED ABSTRACT}

In the 17th century "ephemera" first became subject to collecting activities, with lay collectors and then museum curators, librarians, and archivists becoming interested. After the 1960s, ephemera were evaluated as a new source for history research (cultural, social, local, and city history). After the 1970s, associations were established to collect ephemera, and popular research areas influenced later developments. Simultaneously, archivists made new decisions in this direction. Until this point, the historical documentation strategy for keeping "important" resources for macro history surveys was overtaken, and archivists then extended the strategy of documenting only effective ones' history. Now, keeping documents related to ineffective micro-history studies in archives and investigating them through these new sources have become more possible. Thus, transfer to the future of "important" resources that effectively enlighten history continued, but "unimportant" resources that ineffectively illuminate history have also begun to be transmitted. Indeed, archivists proactively gather ephemera because such documents can usually be collected not only through donations and purchases but also through field research. Archivists are also aware that they collect and value ephemera because of such documents' individual and/or peculiar characteristics.

Furthermore, archivists recognize ephemera by certain features through which they qualify documents for access while keeping ephemera separate from naturally accumulating archival documents. Consequently, archivists do not see ephemera among institutional/personal archival records or records produced from actions/transactions. Ephemera's features can be formulated as follow:

1. Being produced by short-term organizations.

2. Being produced for a short-term purpose.

3. Not being produced to be saved.

4. Being irregular and without continuity.

5. Being produced in different formats.

6. Not requiring an institutional action.

7. Being produced by official and unofficial institutions.

8. Not having a/any archival bond.

9. Having its archival bond removed afterwards.

10. Not being a part of a whole / not providing a basis for an operation / not being a part of a file because of an operation.

11. Break of the institutional bond.

12. Not being involved in the wholeness of the fonds. 
13. Not having a thematic context.

14. Having a resource value.

15. Having a symbolic value.

16. Having a relative resource value.

17. Changeability of utility.

18. Having disconnected parts.

19. Changeability of classification methods.

20. Not being produced by a structure that is organically connected to the archive where it is kept / Not being a natural handover material of the archive where it is kept.

21. Being nondurable.

Having some or all of these features is usually a minimum requirement for archivists to identify documents as ephemera. Based on the literature's definitions of ephemera documents and species, this study discusses questions of ephemera's properties, source value, and, especially, methods of archivists' evaluations. The study used a qualitative research method and, for data analysis, a document analysis technique. 


\section{GíRIŞ}

Etimolojik bakımdan değerlendirmesi ileriki sayfalarda yapılacak olan efemera; farklı gerçek-tüzel kişiler ve geçici organizasyonlar tarafından üretilen, farklı gerçek-tüzel kişiler tarafından koruma altına alınan, dosya ve kurumsal bağı olmayan, bir bütünün parçası olmayan ve farklı tür ve içeriğe sahip materyale verilen genel ve ortak bir isimlendirmedir. Diğer yandan efemera, bir mesleğe ya da bir kuruma aidiyeti ifade etmez. İlk kez 17. yüzyılda koleksiyonerlerin toplama faaliyetlerine konu olan efemera; 20. yüzyılın ortalarından itibaren müzelerin, kütüphanelerin ve arşivlerin de ilgisini çekmiştir. Bu aslında, bir arşivcinin efemerası olduğu kadar; bir koleksiyoncunun, bir kütüphanecinin, bir müzecinin, bir koleksiyonerin, bir sanatçının, bir tarihçinin hatta bir edebiyatçının da efemerası olduğunu bize gösterir.

20. yüzyılın ikinci yarısında bilimsel araştırma konularında tercih edilen yeni eğilimler, yeni kaynak arayışlarını beraberinde getirmiştir. Yeni konu eğilimleri ve bu konu eğilimlerinin gerektirdiği yeni kaynak arayışları, efemeranın da bilimsel araştırmalarda kullanılması muhtemel bir kaynak olarak değer görmesinin önünü açmıştır. Böylelikle, maddi kazanç elde etmeye çalışan koleksiyoncuların yanı sıra; müzecilerin, kütüphanecilerin ve arşivcilerin de bu kaynak türünü toplama faaliyetleri ortaya çıkmış ve efemera araştırmacılara sunulma ihtiyacı duyulan bir materyal türü olarak kabul görmeye başlamıştır. Arşivciler için bu gelişmenin başlangıcını kültür tarihi/sosyal tarih/mikro (yerel) tarih/aile tarihi çalışmaları oluşturmuştur.

Metnin başlangıç kısımlarının belli bir mantık çerçevesinde kolayca okunmasını/anlaşılmasını sağlayacak kısa bir efemera tanımının burada yapılması yerinde olacaktır. Ancak bu tanım, -doğal olarak- arşivcinin efemeradan ne anlaması gerektiği noktasında yönlendirici ve "arşivci bakış açısıyla" olmak durumundadır. Buna göre arşivsel efemera; genellikle kısa süreli özgün bir amaç için, geçici organizasyonlar sırasında, düzensiz olarak ve bir defalık üretilen, karşı cevab1 gerektirmeyen, kurum-dosya-fon bağı olmayan, bir bütünün parçası olmayan/bir bütünden kopartılan, sahadan sonradan derlenen, bir koleksiyon içinde bulunabilen, kaynak niteliği taşıyan, üzerinde kayıtlı bilgi taşıyıcısının değişken olduğu (yazılı, basılı, görsel-işitsel, elektronik vs.) bir materyaldir.

Efemera için önemli problemlerden birisi tanım sorunudur. Efemeradan ne anlaşılması gerektiği; koleksiyonerlerin, müzecilerin, kütüphanecilerin hatta arşivcilerin efemeradan ne anladıkları ve bu meslek mensuplarının söz konusu materyal türünü nereden ve nasıl sağlayabilecekleri önemli bir sorundur. Efemeraya ilgi duyan mesleklerin-kurumların hatta bu meslek-kurum mensuplarının efemerayı tanımlamakta ortak bir yol izleyemedikleri örnekleriyle birlikte ortadadır. Bu çalışmanın temel amacı, -diğer meslek ve kurum sahalarının sınırlarını ihlal etmeksizin- sadece arşivcilerin efemeradan ne anlamaları gerektiği sorusuna mütevazı bir cevap aramaktır. Böylelikle, arşivciler arasında karşılaşılan önemli bir tanım sorununun aşılması ve ortak bir efemera tanımına ulaşılması mümkün olabilecektir. Nitel araştırma yönteminin 
benimsendiği ve durum çalışması olarak kurgulanan bu çalışmanın verileri literatür taraması ile elde edilmiş ve elde edilen veriler de doküman analizi tekniği ile değerlendirilmiştir. Bilimsel kitapların ve makalelerin yanı sıra, gazete haberleri ve mesleki değerlendirmeler de çalışmanın temel kaynaklarıdır.

\section{Kaynak Çeşitliliği İhtiyacının Efemera Üzerindeki Etkisi}

Kaynak; türü, yapısı ve içeriği ne olursa olsun bir konu hakkında çok farklı alanlarda (güncel, tarihi, ekonomik, kültürel, sosyal, siyasal vb.) bilgi veren birincil ve ikincil derecede kaynak değerine sahip malzemedir. İnsanın söylediği, yazdığı, ürettiği, diğer canlıların ve hatta doğal yollarla zaman içinde şekillenen her şey bir kaynaktır. Bu kaynaklar öznenin ve nesnenin kendisi ve öznenin ve nesnenin etkile(n)diği ve/veya şekillendirdiği konu hakkında araştırmacıya bilgi sunar (Keskin ve Somer, 2013, s. 206). Bununla birlikte, geçmişe ait her “iz”, kaynak olarak itibar görmez. Tarihi bir “iz”in kaynak olarak kabul görmesi için, "iz”in fiziki yapısında olan herhangi bir unsurun araştırma eğilimlerine cevap olması veya araştırma eğilimleri bakımından ilgi çekmesi gerekir. Diğer yandan bu durum, tek başına yeterli de olmaz. Bir olayın tarihe mal olması için araştırmacılar tarafından yaygın şekilde örneklendirmeye konu olması gibi, ${ }^{1}$ bir olaya ilişkin "iz"lerin araştırmacılar tarafından benimsenmesi de bir özelliği nedeniyle tercih sebebi olmalarına bağlıdır.

Arşiv belgeleri, araştırmacıların elinde geçmişle bağ kurmayı, onlar marifetiyle geçmişi anlamayı sağlar. Arşiv belgeleri, bu özelliğini; insan hafızasının uzantısı ve temsili olması, bilgiyi kaydetmesi, faaliyetleri belgelemesi, düşünceleri iletmesi, iddiaları ispatlaması, açıklamaları derinleştirmesi, doğruları ortaya koyması ve olaylar hakkında delil olması nedenleriyle kazanır (Dearstyne, 2001, s. 1). Bu da gösteriyor ki, insanı ifade eden (insana bağlı olan, ona hizmet eden, onu anlatan, onun mevcudiyetini, faaliyetini, zevklerini ve oluş biçimini ortaya koyan) her şey tarihin araştırılmasında kullanılır (Atlansoy, 1997, s. 15). Bu nedenle geçmişe

1 E. H. Carr, Stalybridge Wakes'de (İngiltere) 1850 yılında, bir zencefilli çörek satıcısının küçük bir tartışma sonucu kızgın bir kalabalık tarafından dövülerek öldürülüşünü, bu olayın tanığı olan bir kişinin 1926 yılında az bilinen günlüğünde anlattığını (Sanger, 1926, ss. 188-189), ancak bunun tarihçiler arasında tarihi bir olay olarak değerli bulunmadığı için hemen hiç zikredilmediğini yazar. Bununla birlikte, olayı 1962 yılında yayınlanan The Making of Victorian England adlı eserinde tek zikreden yazarın Kitson Clark (1962) olduğunu belirtir. Bu olayın yaygın bir örneklendirme olarak tarihe mal olmasının ancak başka araştırmacılar tarafından benimsenerek anlatılmasına bağlı bulunduğu üzerinde ayrıca durur (Carr, 1961, ss 12-13; Carr, 1980, s. 18). Konu için verilebilecek bir başka örnek Dr. M. Fahri Furat tarafından yayınlanmıştır. Furat (2014, ss. 251-278), Ukrayna’nın doğusunda Poltava bölgesinde yer alan ve Osmanl1-Rus harpleri boyunca esir Osmanlı askerlerinin tutulduğu kasabalardan biri olan Valki'de esir tutulan 642 Osmanlı askerinden 400'den fazlasının kasabada gelişen bir olay nedeniyle katledildiğine dair hadisenin bir hatırat kaynak gösterilerek yerel Silski Novyny gazetesinde "Valkivska rozprava nad Turkamy u 1829" başlığı ile yayınlandığını, Başkanlık Osmanlı Arşivi'nden ve Ukrayna'da Derzhavniy arhiv Harkivskoyi oblasti'den (Harkiv Bölgesi Devlet Arşivi/Kharkov Region State Archive) olaya ilişkin kayıtlara ulaştığını, olayın 1812 yılında meydana geldiğini ve hadiseye ilişkin belgelerin ilk kez kendisi tarafından ancak 202 yıl sonra bir araştırmaya konu olduğunu belirtir. Bu her iki örnek de göstermektedir ki, bir araştırmanın belgelenmesinde kullanılabileceği gerekçesiyle arşivci tarafından seçilerek saklanan her belge yaygın şekilde araştırmacıların dikkatini çekmediğinde nadiren kullanılır veya hiç kullanılmayabilir. 
ilişkin izler, birer tarihi kaynak olarak oluştu(ruldu)ğu döneme ait tanıklıktır ve geçmişle bağ kurulmasinda belirleyicidir.

Araştırmalar sırasında birbirinden farklı kaynaklar kullanılır. Kaynağın farklılığı; üretildiği dönemden, fiziki yapısından, bilgisel değerinden ve mülkiyetinde olduğu kurumdan ileri gelir. Kaynak önemli ve özgündür; ancak bir konu üzerindeki işlevi genellikle sınırlıdır. Konuyu belirli bir bakış açısıyla değerlendirme imkânı verir, sınırlı bilgi içerir, genellikle farklı yorum imkânı vermez ve yeterli derecede belgelendir(e)mez (Keskin ve Somer, 2013, s. 205). Tüm bunlar kaynakların araştırılan konunun aydınlatılmasındaki işlevinin, araştırmaya kattığı değerin ve doldurduğu boşluğun değişken olduğunu gösterir. Bu durum, iyi bir araştırmanın veya bilimsel çalışmanın farklı kaynaklarla desteklenerek tamamlanmasını gerekli kılar.

Araştırma eğilimleri 20. yüzyılın ikinci yarısından itibaren, -İkinci Dünya Savaşı sonrasında Fransa, İngiltere, Amerika Birleşik Devletleri ve Kanada gibi Batılı devletler tarafından geliştirilen yeni toplum mühendisliği ihtiyaçları nedeniyle- kültür tarihi alanına doğru kaymıştır. Uzun süren savaşlar ve bu savaşların (çok milletli, çok dinli, çok mezhepli kısaca çok kültürlü karmaşık toplum yapılarına sahip) devletlere ve toplumlara getirdiği mali yükün yanı sıra, Batılı toplumların savaşın neden olduğu yıkımla derinleşen toplumsal travması, araştırma eğilimlerinin belirtilen yöne doğru meyletmesini bir bakıma zorunlu kılmıştır. Özellikle sömürge döneminin köleleri ve onların özgür nesli ile mevcut toplumsal yapının harmanlanarak oluşturduğu yeni ortak değerlerin güçlendirilmesini ve bireyler tarafından paylaşılmasını önceleyen; böylelikle barışık bir toplum inşa edilmesi ile ilgilenen bu yeni devlet politikasının toplumsallaşabilmesi ve kabul görmesi için farklı uygulamalar geliştirilmiştir. Bu uygulamalardan birisini de, tarihçilerin -resmi tarih anlayışını terk ederek ve aslında yeni bir resmi tarih ideolojisi benimsediklerinin farkına varmayarak- kültür tarihi konularına meyletmeleri oluşturmuştur. Özellikle ilk ve ortaöğretim süreçlerinde ören yerlerinin, müzelerin ve arşivlerin ziyaret edilmesi/kullanılması (Keskin, 2014, ss. 43-66) böyle bir ihtiyacın bilgi kurumları özelinde de karşılanması anlamına gelmektedir. Yine kültür tarihi, sosyal tarih, yerel tarih gibi konular üzerine yapılan yayınların sayıca giderek artması ve araştırma konuları olarak yaygınlık kazanıp geniş bir kabul görmesi böyle bir resmi politikanın araştırmacılar tarafından fark edilmeksizin yaygın bir şekilde benimsendiğinin göstergesidir. Ayrıca şu da açıkça belirtilmelidir ki, kuşkusuz devlet politikaları bakımından her iki yaklaşım da doğrudur; ancak "içinde art niyet barındırmayan saf insani değerler ile bakıldığında" ise kesinlikle ikinci yaklaşımın makul olduğunu söylemek gerekir.

İkinci Dünya Savaşı'ndan sonra pek çok yeni konu araştırmacıların ilgisini çekmiştir. 1960'ların kişisel haklar, kadın hakları, cinsiyetçilik, sosyal adalet, etnik ve ırksal azınlıkların durumu, zenci tarihi, yoksulluk, cehalet, delilik, hastalık, savaş karşıtı hareketler, aile ve şehir tarihi gibi kültür tarihinin daha pek çok ayrıntılarının incelenmesi, tarihçiler için yeni araştırma konularının odak noktasını oluşturmuştur. Bu da "bir avuç elit yerine bütün bir toplumun tarihi deneyimini” anlamak anlamına gelmektedir (Tosh, 1997, s. 97). Böylelikle, insan faaliyetlerinin 
bütün boyutları araştırmacıların ilgi alanına girmiştir. Ne var ki araştırmacılar, arşivlerdeki materyalin özellikle siyasi tarih ve ekonomi tarihi merkezli olması nedeniyle, yeni araştırma konularını arşivlerden yeterince destekleyememişlerdir. Bu gelişme, bir yandan toplumsal belgeleme stratejisinin yeniden kurgulanmasını gerekli kılmış; diğer yandan da arşivlerde bulunma ihtimali olmayan ancak toplumsal yaşamın belgelenmesinde kullanılabilecek yeni kaynakların arşivlere kazandırılmasını ve bu kaynakların arşivler yoluyla araştırmacılara sunulması imkânını beraberinde getirmiştir.

Bilgi kurumları çalışanları özelde de arşivciler tarafından -araştırma değerlerinin henüz keşfedil(e)memiş olması yüzünden- değer verilmeyen, bu nedenle de korunmayan bir kaynak türü olan ve poster, fotoğraf, ilan, afiş gibi pek çok türü bulunan efemera -yukarıda belirtilen nedenlerle- bir araştırma kaynağı olarak dikkatleri üzerine çekmiştir. Geleneksel kaynaklardan sonra sözlü tarih kayıtları, ilk akla gelen kaynaklar olmuştur (Burant, 1995, s. 190). Çok geçmeden gündelik yaşama ait ve genellikle mevcut kaynaklarda bulunmayan enformasyonu sunan efemera, araştırmacıların ilgisini uyandırmıştır. Bu yeni kaynak türü, diğer kaynaklarda dikkat çekmeyen popüler düşünce ve kültürün pek çok alanını resmetmektedir (Burant, 1995, s. 190). Bu konuyla ilgili çalışmalardan biri, sanat tarihçisi Süleyman Faruk Göncüoğlu (2010, ss. 327-355) tarafından yapılmıştır. Bu çalışmada; fotoğraf, efemera ve sözlü tarih çalışmasından oluşan üç ayrı kaynağın bir semt tarihinin yazılmasında sağlayacağı yararlar Atikalipaşa (Atikali) Semti (İstanbul, Fatih) örneğinde anlatılmıştır. Bu materyal grubu, ilk önce koleksiyonerlerin, daha sonra da müzecilerin, kütüphanecilerin ve -kültürel belleğin parçasını oluşturmaları nedeniyle- arşivcilerin dikkatini çekmiştir (Keskin ve Somer, 2013, s. 209).

Arşivci ve tarihçi bu noktada önemli bir soruyla karşı karşıyadır. Bu soru, 'efemeranın sahip olduğu bilgi içeriğinin nasıl ortaya çıkartılabileceği’ ile ilgilidir. Bilgi kurumlarının ilgi duymasıyla birlikte, özellikle 20. yüzyılın ikinci yarısından itibaren kültürel belleğin bir parçasını oluşturduğu bilinen efemeradan hangi yolla(rla) bilgi sağlanabileceğinin veya bu kaynak türünden yararlanma bakış açılarının belirlenmesi bu yüzden önemlidir. Fatma Acun'un (2011, ss. 423-434) görsel belgeler için belirlediği yararlanma kriterleri, efemera türü belgeler için de geçerli olabilecek ayrıntıya sahiptir. Buna göre efemera türü belgeler, nitelik (muhteva) ve nicelik (sembolist/semiyotik analiz, imaj analizi, eşli zıtlıklar, bağlam, tür, özdeşleştirme, hikâyeleştirme, okuma, işaret eden ve işaret edilen, konum rolü) bakımlarından analiz edilebilir. Diğer bir ifade ile efemera türü belgelerin farklı yapıları, söz konusu yararlanma kriterlerinin tamamının bu belgelere de uygulanabileceğine işaret etmektedir.

The Chartered Institute of Library and Information Professionals (CILIP) adına Efemera Çalışma Grubu tarafından hazırlanan CILIP Raporu'na göre (CILIP, 2003, s. 10); “Efemera, farklı muamele edilmiş ya da diğer dokümanların ihmal edebilecekleri nitelikteki ayrıntıları gösteren bir türdür ve çoğu kez içeriği, dili ve çizgesel tarzı ile bir durumun veya bir dönemin ruhunu çağrıştırarak iletir.”. 20. yüzyılın son çeyreğinde Marvin J. Taylor (2002, ss. 32-52) tarafından 
New York şehir merkezinin ana hattında olmayan sanat ve müzik durumunu belgelemek için geleneksel materyalin kesinlikle yeterli olmadığı sonucuna varılmış; bu konuları belgeleyen materyalin çoğunun efemera türünde (posterler, fotoğraflar, ilanlar ve buna benzer materyaller şeklinde) materyal oldukları değerlendirilmiştir (Launder, 2002, s. 70). Taylor (2002, s. 43) ilanları incelemek suretiyle; sanatçılar, yazarlar ve icra yerleri arasında var olan ilişkileri kurmuş; böylelikle üzerinde çalıştığı kültür anlayışını yeniden kurgulayabilmiştir. Bu örnek göstermektedir ki kütüphanelerin ve arşivlerin geleneksel koleksiyon sınırları ile hareket etmeleri kültürel izlerin korunması amacına tam olarak hizmet etmemektedir (Launder, 2002, s. 70). Sıra dışı karakteri ve kültür tarihi için taşıdığı olağanüstü değeri nedeniyle efemera dikkat çekicidir. Örneğin; ticaretle ilgili tarihçeler, rehberler ve haritalar görünürde basit ve yalındır; bununla birlikte araştırmacılar tarafından farklı konuların araştırılmasında kullanılabilmektedir.

Efemeranın değerini fark eden diğer bir uzman grubu, basım ve grafik tasarım tarihçileridir. Basım ve grafik tasarım sahasıyla ilgilenen tarihçiler; 19. yüzyılın başından itibaren efemeranın baskı teknolojisinin gelişmesinde, tür tasarımı ve çizgesel imgelerin evriminde itici bir güç oluşturduğunun farkına varmışlardır. Baskı tasarımı ve üretimi ile ilgilenen bir bilim insanının; değerli evrak basımı, reklâm, yönetsel ve ticari baskı konularında bilgi içeren efemerayı kitap tarihiyle birlikte dikkate alması gerekir (CILIP, 2003, s. 10). Diğer yandan efemera, edebiyat alanında da kullanılabilmektedir. Örneğin; edebiyat alanında (tarihi bir konu bağlamında) eser (bir roman, bir şiir vs.) kaleme alan bir yazarın dönemin ruhunu tam olarak yansıtabilmesi (tadını almak/havasını koklamak ve o dönemle ilgili ilave bilgiler bulabilmek) için o dönemde üretilmiş efemeraya bakması gerekmektedir (Makepeace, 1985, s. 207). Ayrıca efemeranın kullanımına ilişkin bir sınır da yoktur. CILIP Raporu (2003, s. 11)'nun da işaret ettiği gibi, efemera sergilerin ve eğitimsel sunumların hazırlanmasında vazgeçilmez gösterim malzemesi olarak ayrı bir değere sahiptir. Yerel iş yerlerinin, kurumların ve örgütlerin geçmişlerini, etkinliklerini ve başarılarını anlatan broşür ve el ilanları; demir yollarının, hava yollarının ve otobüs şirketlerinin bastıkları sefer rotalarını ve sefer hareket saatlerini gösteren broşürler; iş ve eğitimle ilgili kurumlar tarafından ürünlerini ve hizmetlerini tanıtan farklı tipte kataloglar (Kyvig ve Marty, 2000, s. 140); üzerlerinde kayıtlı olan resimleri ve desenleri, büyüklükleri, renkleri, sayıları incelenerek ait oldukları dönemin olayları ve dönemin özellikleri, toplumsal inanışlar, geçiş dönemlerinin yansımaları ile önemli ipuçları veren pullar (Acun, 2011, s. 140), efemeranın değerine değer katmaktadır.

Efemera; sadece bir konunun bilimsel, sanatsal vs. yönünün aydınlatılmasında işlev görmemektedir. Efemeranın hukuk alanında rol oynayabildiğinin de farkında olmak gerekir. Yakın tarihimizde Türkiye'nin karşı karşıya kaldığı uluslararası davalardan birinin kazanılmasında efemeranın belirleyici olması buna bir örnektir. Uzan Grubu'nun Türkiye Cumhuriyeti Hükümeti aleyhine açtığı 10,1 milyar dolarlık tazminat davasında; davacının iddialarını çürütmekte kullanılan en önemli delillerden birisi, hava yolu uçuş listelerini toplayan bir koleksiyoncudan 
satın alınan hava yolu kitapçığı olmuştur. Bu kitapçık sayesinde, davacının iddia ettiği tarihte bir uçuş olmadığı saptanmıştır. Bu durum, ayrıca uçuş sonrasında kalındığı iddia edilen otel kayıtlarının incelenmesini gerektirmiş;; otelde kalınmadı̆̆ı böylelikle tespit edilmiş; dolayısıyla iddiaların yalan olduğu ispatlanmış ve dava reddedilmiştir (Güler, 2011, s. 8).

Bütün bu bilgilerden hareketle denilebilir ki -David E. Kyvig ve Myron A. Marty (2000, ss. 45-46)'nin de ifade ettiği üzere- efemeranın -en basit anlatımla- bireylerin/toplumun/ toplulukların geçmişiyle ilgili, onları üretenlerin hayal edebileceklerinden çok daha fazla şeyi açıklama ihtimali vardır.

\section{Gündelik Yaşamın Belgelenmesinde Yeni Arayışlar}

Efemera 1960 sonrasında muhtemel okuyucu kitleleri arasında derin merak uyandiran kültür tarihi, sosyal tarih, yerel tarih, şehir tarihi, aile tarihi araştırmaları (bundan böyle sadece kültür tarihi olarak anılacaktır) için önemli kaynaklar olarak görülmüştür. Bu bakış açısı, efemeranın özellikle tarihçiler arasında popüler bir kaynak türü olarak yaygınlık kazanmasını sağlamıştır. Kültür tarihi araştırmalarında yararlanılan bir kaynak olma değeri nedeniyle efemera, araştırmacılar arasında giderek artan bir ün kazanmıştır. Bilinen ilgi alanlarının kaynaklarını ihtiyaç duyan araştırmacılara/meraklılara sunmayı bir sorumluluk olarak benimsemiş olan/yasal yükümlülükleri arasında araştırmacılara -ve kurumlar da çalışanlarına- faaliyet gösterdikleri ülkelerin özellikle milli tarihlerini aydınlatacak kaynakları hazır bulundurması gereken bilgi merkezleri (arşivler, kütüphaneler ve müzeler) de zamanla bu kaynakları/dermeleri/ koleksiyonları sorumluluk alanlarına dâhil etmişlerdir. Bu durum, aynı zamanda söz konusu bilgi merkezlerinin kaynak-derme-koleksiyon geliştirme stratejilerini değiştirmelerine/yeniden tanımlamalarına yol açmıştır. Bunlardan birini de bilgi merkezi türleri arasında yer alan arşiv kurumları oluşturmaktadır.

1970 yılı sonrasında, yerel ve ulusal düzeyde faaliyet gösteren derneklerin efemera toplama konusunda etkin olmaya başladıkları görülmektedir. Aynı yıldan sonra arşivciler de bu konuda inisiyatif almaya başlamışlardır. Bu gelişmenin kültür tarihi çalışmalarının da etkisiyle meydana geldiğine kuşku yoktur. Kültür tarihi konularının 20. yüzyılın ikinci yarısının ilerleyen yıllarında merak uyandırması, insanın kendisine dair gizemli ayrıntıları içinde barındırması bunun bir sonucudur. Bu gelişmeler arşivcileri yeni kararlar almak zorunda bırakmıştır. Nitekim aynı yıllarda Avrupa genelinde karşımıza çıkan aile tarihi araştırmalarının popüler şekilde yoğunluk kazanması (Ketelaar, 2009, ss. 9-28) bu gelişmeden bağımsız düşünülemez.

Arşivciler kültür tarihi çalışmalarının etkisi altında kalarak 20. yüzyılın son çeyreğine yeni toplumsal belgeleme stratejisi geliştirme çabaları içinde girdiler. Mesleki çevre tarafindan “arşivsel analiz çağı”" (Dearstyne, 2001, ss. 43-44) şeklinde adlandırılan bu döneme belirtilen gelişmeler damgasını vurdu. Kısa bir süre sonra, arşivciler mesleki toplantılarında bu konuya 
yer vermeye başladılar. Bunlardan ilki 1976 yılında Association of American Archivists tarafından düzenlenen konferansta gündeme geldi (Burant, 1995, s. 193). Gündelik yaşamın belgelenmesi konusunda yeni arşivcilik yaklaşımını ele alan bu toplantılar, aynı derneğin 1986 ve 1992 yıllarındaki diğer iki toplantısı ile devam etti. Toplumsal yaşamın belgelenmesinde yetersiz kalan geleneksel belge devralma stratejisinin genişletilmesi bu toplantılarda özellikle tartışıldı. "Analiz Çağı"nın bir gereği olarak, belge toplama stratejisinde yeni bir istikamet belirleyen "Dokümantalist Yaklaşım” benimsendi ve gündelik yaşamın belgeleri için etkin (aktif) bir eğilim hedeflendi.

“Dokümantalist Yaklaşım”ın benimsendiği “Analiz Çağı”nda ilk olarak makro-siyasi tarih araştırmaları bakımından "önemli” kaynakları tutmaya yönelik olan geçmişi belgeleme stratejileri gözden geçirildi ve arşivcilerin artık ilkeleri belirlenmiş olan koruma stratejileri (saklama planları) yeniden şekillendirildi. Sadece etkin olanların tarihinin belgelenmesi yönünde belirlenmiş olan karakteristik belgeleme stratejisi böylelikle esnetildi ve mikro tarih çalışmalarının genel anlamda ana teması olan "etkin olmayanların tarihinin arşivler yoluyla araştırılması" ancak bu yeni gelişme sayesinde mümkün hale gelebildi (Tosh, 1997, ss. 52, 97). Böylelikle sadece etkin olanların tarihini aydınlatacak “önemli” kaynakların geleceğe aktarılmasının yanı sıra etkin olmayanların tarihini aydınlatacak -ve etkin olmayanlar hakkında bilgi veren- “önemsiz?” kaynakların geleceğe aktarılması yoluna gidilmeye başlandı. Bu tartışmaların nihayetinde arşivcilikte Theodore R. Schellenberg (1985, ss. 269-279; 2008, ss. 55-70) tarafından geliştirilen ve bir süredir uygulanan önemlilerin tarihinin belgelenmesine dayanan geleneksel belgeleme teorisi/stratejisi genişletildi ve toplumsal yaşamın bütün yönlerini aydınlatmaya dayanan genişletilmiş yeni bir belgeleme stratejisi arşivcinin gündemine alındı. Kurumlar ve kişiler tarafından üretilen ve belirlenmiş olan saklama planlarına göre imhası söz konusu olan kayıtlar arasından mantıklı bir kısmının örnekleme tekniği ile seçilerek geleceğe aktarılması (Kepley, 1984, ss. 125-130; Bradsher ve Ambacher, 1992, s. 1; aktaran Pamuk, 2017, s. 4) böylelikle söz konusu oldu. Bu uygulama, bir bakıma genellikle kurumsal bir niteliği olmayan gündelik yaşama ait kaynakların, yani efemera türü belgelerin sahadan toplanmasını da mümkün hale getirdi.

Gelecekte geçmişin toplumsal yüzünün tümüyle belgelenmesinde yeterli olunamayacağ esasına dayanan eski belgeleme stratejisine yönelen değişim rüzgârı, kısa zamanda popüler hale geldi. Bu gelişme mükelleflerce bir taraftan geleneksel olarak uygulanmakta olan arşivlere belge devir uygulamasının devam etmesini, bir taraftan da belgelemenin yeni yollarla geliştirilmesini sağladı. Arşivcilerin üzerine yeni sorumluluklar yükleyen bu gelişme, üretilen belgelerin doğal olarak devrinin söz konusu olmadığı ve kısa süreli/geçici etkinliklerde ve kısa süreli organizasyonlar tarafından üretilen ve farklı nedenlerle üretim yerlerinden ve dosya ilişkilerinden kopartılan belgelerin kaderinin değişmesini de beraberinde getirdi. Nihayet geleneksel olarak pasif rol almaya dayanan ve belgelerin kendilerine devrinden sonra sorumluluklarını yerine 
getiren arşivcilerin belgeler üzerindeki pasif rolleri -belge yönetimi uygulamasından sonradeğişmeye ikinci kez yüz tuttu. Bunun üzerine arşivciler; efemera türü belgelerin bizzat sahadan toplanacağının farkında olmaları nedeniyle, sahaya inmekten yüksünmediler, etkin bir belge toplama faaliyeti benimseme yoluna gittiler (Keskin ve Somer, 2012, ss. 35-41).

Kaynak değeri güçlü olduğu artık anlaşılmış olan efemeranın arşivlerin malzemesi haline getirilebilmesi kolay değildir. Bunun çok belirgin iki nedeni vardır: 1) Efemera türü belgelerin, arşiv idarelerinin doğrudan ve yasal devir sorumlulukları arasında olmaması, 2) bu belgelerin sahadan ve inisiyatif kullanılarak belirlenen aktif bir toplama (derleme-sağlama) politikası gerektirmesi. Bu iki nedenle arşivci, efemerayı -ülkesinin arşiv mevzuatı ve bütçe imkânları² izin verdiği ölçüde- doğal devir yöntemiyle ve -diğer kaynaklar için olduğu gibi- genellikle saha taraması yoluyla ve bilgisel değeri nedeniyle toplar.

\section{Efemeranın Toplamaya Konu Olması}

Efemera yaklaşık olarak 400 yıldır gündemde olan bir konudur. Örneğin; 17. yüzyılda bazı koleksiyoncular (John Selden -1584-1654-, Samuel Pepys -1633-1703- ve John Bagford -1650-1715-) el ilanları gibi efemera materyali toplamışlardır. Bunlar arasından Bagford ve Selden' in topladıkları efemera günümüze kadar ulaşmıştır (The Ephemera of Trade, 2001). Bu girişimlere 19. yüzyılda Sarah Bankes (1823-1904) ve Baron Anselm Salomon von Rothschild (1803-1874) de dâhil olmuştur. Onlar kartvizit türünden efemera materyali biriktirmişlerdir. 20. yüzyılda ise Sir Ambrose Heal (1872-1959) ve John Johnson (1841-1917) gibi pek çok kişi efemeraya ilgi duymuş ve onu toplamıştır (CILIP, 2003, s. 7; John Johnson Collection Exhibition, 2001; The Ephemera of Trade, 2001).

20. yüzyılın başlarında efemeraya yönelen kişisel ilgi, aynı yüzyılın son çeyreğinde kurumsal ilgiyle birleşerek, daha popüler bir geleceğin yolu açıldı. Yerel, ulusal ve uluslararası düzeyde faaliyet gösteren derneklerin bu dönemden itibaren faaliyetleri söz konusudur. 1975 y1lında kurulan Ephemera Society, bunların ilkini oluşturur (de Beaumont, 2010). Ayrıca yerel düzeyde Ottawa Collectors'Society, ulusal düzeyde Ephemera Society of America (1980), Ephemera Society of Australia (1987) ile Ephemera Society of Canada (1989) ve uluslararası düzeyde faaliyet gösteren International Ephemera Council bilinenler arasında yerlerini aldılar (Burant, 1995, ss. 189-190; Stone, 1998, s. 102). Bunlara ek olarak, efemera sergileri açıldı. National Archives of Canada tarafindan 1980'lerde iki sergi (Burant, 1995, s. 193), Diana Tardif-Cote tarafindan 1983 yılında Painters of Canada Series Exhibition of Christmas Card adıyla bir

2 Efemera türü belgelerin arşivciler tarafından derlenmesi ciddi bir maliyeti gündeme getirmektedir. Anlık organizasyonlarda anlık olarak derlenen efemeranın toplanması muhtemelen hiçbir bir maliyet gerektirmeyecektir. Ancak antika/eski eser niteliğindeki efemeranın edinilmesi oldukça pahalıdır. Örneğin; Osmanlı döneminde basılmış olan "Talebe Defteri “ dergisinde yer alan "Osmanlı parasını boşa harcamaz” ibaresini instagramda paylaşmak üzere edinen Dr. M. Fahri Furat, söz konusu derginin ilgili sayısına 40 TL ödemek zorunda kalmıştır (Dr. M. Fahri Furat, kişisel iletişim, 7 Haziran 2018). 
sergi, Lydia Foy tarafindan 1984 yılında In the Best Style of the Art Commercial and Fine Art Prints in Canada 1850-1950 adlı diğer bir sergi düzenlendi.

Arşivlerin yanı sıra kütüphane ve müzeler de efemera toplama eğiliminde oldular. Artık bazı ülkelerin milli kütüphanelerinin yanı sıra halk kütüphaneleri de efemera toplamaktadır. Örneğin; Avustralya'nın devlet ve bazı eyalet kütüphaneleri efemerayı aktif biçimde toplamaktadır. 1960 yılından beri Avustralya Milli Kütüphanesi; Avustralya yaşamı, sosyal hayatı, gelenek-görenekler, popüler kültür, kamunun ilgilendiği ulusal olaylar ve konular ile ilgili efemerayı toplamaktadır (National Library of Australia, 2011). Ayrıca Victoria eyalet kütüphanesi olan Manuscript Division of the State Library of Victoria, politik gösteriler sırasında dağıtılan materyalleri ve ilanları toplamaktadır. Bunun için düzenli olarak parlamento meydanlarına görevlendirdiği bir personelini göndermektedir. Yine The State Library of New South Wales (Avustralya) resmi olarak efemera için özel bir depo oluşturmuş ve buraya -işi New South Wales halkını ilgilendiren bütün efemera türü materyalden bir örnek derlemek olan- bir efemera kütüphanecisi tayin etmiştir (Organ, 1987, ss. 105-118; Burant, 1995, s. 194). Efemerayı sahadan derleme faaliyetinin kütüphane bütçesine önemli bir yük getirdiği de göz ardı edilmemelidir.

20. yüzyılın son çeyreği, arşivcilerin efemera ile ilgilendikleri bir dönem olmuştur. 1976 yılından itibaren Society of American Archivists tarafindan her yıl düzenlenen konferanslar, bu türden etkinliklerin başlangıcını oluşturur. Söz konusu dernek tarafından bu konferansların 1976, 1986 ve 1992 yıllarında düzenlenenleri toplumsal hafızanın/mirasın belgelenmesi konusunda yeni bir arşivcilik yaklaşımıyla ilgilidir. Etkin (aktif) olmayan geleneksel belge devralma stratejisinin değişmesi/genişletilmesi konusunda bir eğilim burada açıkça kendisini hissettirmektedir. Toplumsal hafızanın her yönünün belgelenmesine yönelik bir hedef belirleyen "Dokümantalist Yaklaşım" tarihi belgelerin bizzat sahadan toplanmasını içeren etkin (aktif) bir eğilimi hedeflemektedir. Bu yeni yaklaşım 1991 yılında Association of Canadian Archivists tarafından Banff (Kanada)'da düzenlenen çeşitli konferanslarda ele alınmış; aktif ve pasif yaklaşımların efemeranın sağlanmasındaki rolleri değerlendirilmiştir (Burant, 1995, s. 193). Efemeranın içeriği, dili ve çizgesel tarzı ile diğer dokümanlarda bulunmayan ayrıntılara sahip olma ihtimali bu değerlendirme faaliyetinin önemini daha da artırmıştır. Diğger yandan bu konu, bazı eserlerde araştırma konusu olmuştur. Kanada'da efemera konusunda arşivsel uygulamalarda temel el kitabı olarak görülen A Manual for Small Archives (1988) bunlardan biridir. Bu eserde; efemeranın önemli bir arşiv belgesi olduğu, daha çok aktif bir yaklaşımla sahadan sağlanabileceği, efemera fonları oluşturulması gerektiği savunulmaktadır. Bu amaçla toplumsal hareketler (toplumsal mitingler, politik ve sosyal toplantılar, tiyatro ve diğer olaylar) ile ilgili materyalin arşivlere kazandırılması önerilmektedir (Coles, 1988, s. 148). Bu aktif yaklaşım, Kanada'nın geleneksel belgelerden ziyade gündelik yaşamın ayrıntılarını belgeleyen malzemenin derlendiği bazı arşivlerinde uygulanmaktadır (Burant, 1995, s. 193). 


\section{Efemerayı Nasıl Tanımladılar?}

Efemera kelimesinin etimolojik kökeni, 14. yüzyıla dayanır. Bu dönemde tıbbi bir terim olarak kullanılan efemera (Online Etymology Dictionary, 2011), daha sonraları genel olarak gündelik yaşama ilişkin ıvır zıvır, kısa ömürlü, hacimsiz ve geçici materyal şeklinde değerlendirilmiştir. Ancak efemeranın tanımı ve içeriği; ona sahip olan/ondan yararlanan kişi, meslek ve kurumlarca zamanla gözden geçirilmiş ve elde edilen kazanç/yarar bakış açısıyla yeniden açıklanmıştır. Önemli bazı kaynaklarda efemeraya ilişkin şu bilgiler geçmektedir:

The Oxford English Dictionary Online (2011), efemeranın kökenini eski Yunancaya dayandırır. Buna göre efemera; ephemeron (epi=bir, hemera=gün) kelimesinin çoğulu (İngilizce: ephemera) olup, "bir günden fazla dayanmayan"; -16. yüzyıl sonlarına doğru tekil haliyle kullanılan bu kelime- bir günde solan çiçek, ya da ömrü çok kısa süren böcek; -18. yüzyıl sonlarında- kısa süreli ilgi çeken şeyler ya da kişiler için kullanılmıştır. Daha sonraları efemera iki anlamda kullanılmıştır:

1. Sadece kısa bir süre var olan/kullanılan/beğenilen/yararlanılan şeyler.

2. Başlangıçta sadece kısa bir süre için yararlı veya popüler olması beklenen toplanabilir materyal.

Bu da, kelimenin başlangıçta kısa ömürlü böcekleri ve bitkileri, daha sonra kısa süreli ilgi çeken şeyleri/kişileri tanımlamaktan zamanla biriktirilmek amacı ile üretilmemiş kısa ömürlü ve önceleri fazla değer taşımayan, ancak sonradan bazı koleksiyoncular tarafından koleksiyon malzemesi haline getirilen ve "1vır zıvır" olarak düşünülen ürünlere verilen genel bir ad şekline dönüştüğünü göstermektedir.

Shorter Oxford English Dictionary, efemerayı ilk önce; "biletler, posterler ve tebrik kartları gibi kısa süreli kullanımlar için üretilen basılı veya yazılı parçalar”, daha sonra da "bir koleksiyoncunun topladıkları dışında uzun süreli niteliği taşımayan basılı şey"; "çoğu basılı halde bulunan, özel olarak üretilen ve sonra atılan geçici günlük kâğıt parçaları" (CILIP, 2003, ss. 12-13; Rickards, 1997, s. 7) olarak tanımlar. Makepeace (1985, s. 10) ise -standart kütüphane malzemesinden farkını vurgulayan ve dayanıksız olduklarını, özel bir amaç için üretildiklerini, birincil ya da ikincil kaynak niteliği taşıdıklarını ifade eden- "baskı veya resimli üretilen, fakat kitap, broşür veya dergilerin dışında olan, eylemsi veya aydınlatıcı mesaj taşıyan materyallere verilen ortak isim" olduğunu belirtir.

A Manual for Small Archives adlı eserde ise efemera, "periyodik üretilmeyen, kullanılmak ve daha sonra atılmak üzere tasarlanan, günlük ve geçici materyal” (Coles, 1988, s. 146; Ephemera News, 1991), "kısa sureli bir amaç için özgün bir girişimi sunmak veya belirli bir olayı bildirmek üzere basılmış olan herhangi bir materyal” (Burant, 1995, s. 190) şeklinde 
açıklanmıştır. Avustralya Milli Kütüphanesi, efemerayı: "Beş sayfadan daha fazla olup, arasında sanat galerileri katalogları ve ticari kataloglar gibi türlü baskıların yanı sıra milli organizasyonlar, özel etkinlikler, federal seçimler, gösteri sanatları şirketleri gibi çeşitli baskı kaynaklarının bulunduğu parçaların seri ya da monografi olarak korunması için durum bazında değerlendirilmesi gerektiği, fakat tutarlılık ve uygunluk sebebiyle bazen onların efemera olarak işlem görmesi gerektiği” (Stone, 1998, s. 100) şeklinde tanımlar. Roberts (1993, s. 412), efemerayı, "arşivciler, kütüphaneciler ve müze yöneticileri tarafindan, genellikle bask1 şeklinde olan, kısa dönemli ya da geçici amaçlar için üretilen geniş bir yelpazedeki materyali tanımlamak için kullanılan bir terim" olarak görür. Acland (1993, s. 470), efemerayı "kısa zamanlı geçerlilik süresine ve düşük yoğunluklu değere sahip parçalar" olarak verir. Roberts (1993, s. 412), efemera için belirlenen bazı ortak nitelikleri şöyle sıralar: 1) Efemera normal olarak kısa dönemli ya da geçici bir amaç için üretilir, 2) genellikle görünüşüne bakılarak ıvır zıvır olarak değerlendirilir, 3) çoğunlukla baskı ya da fotokopi şeklinde üretilir, 4) sıklıkla küçük, tek dokumanlar ya da objeler biçiminde görülür. Efemera için Keeping Archives (1993) adlı eserde verilen açıklamalarda kütüphane, müzeci ve koleksiyoncu bakış açıları birleştirilmiştir. The Encyclopaedia of Ephemera (2000) koleksiyonerler, küratörler ve tarihçiler için gündelik yaşamın bölük pörçük/parçalar halindeki dokümanları olarak gördüğü efemeranın bir bütünün parçası olmaması, arşivsel bağlamıyla ilişkisinin kesilmiş olması ve tek olarak bulunması niteliklerini ifade etmektedir (CILIP, 2003, s. 12; Young, 2003, s. 25).

Dictionary of Archival Terminology adlı mesleki terminoloji sözlüğünde efemera, genellikle simge niteliğinde olduğu için saklanır, resmi ve gayrı resmi olabilir bir yapı tarafından üretilebilir bilgi taşıyıcısıdır (Dictionary of Archival Terminology, 1984, s. 70). Bu eserin geliştirilerek yapılan Türkçe çevirisinde efemera -genellikle kelime olarak Türkçede aynen kabul edilmekle birlikte- “döküntü” şeklinde Türkçeye çevrilmiştir (Arşivcilik Terimleri Sözlüğü, 1995, s. 29) ve Dictionary of Archival Terminology'deki açıklama burada anlam itibariyle aynen ("bazen örnek olarak saklanan, geçici değere sahip gayri resmi belgeler” olarak) verilmiştir.

Efemera konusunda bir açıklama da Alman arşivci Angelika Menne-Haritz tarafindan yapılmıştır. Menne-Haritz (1999, s. 97), hazırladığı mesleki terminoloji sözlüğünde Almanca "Weglegesachen" terimi ile verdiği efemerayı bir faaliyetin parçası olmadıkları için karşı bir işlemi gerektirmeyen, resmi bir kurum tarafından üretilebilen, dosya bağı olmayan belgeler şeklinde açıklar.

İki ayrı Türkçe terminoloji sözlüğünde efemera, "kısa ömürlü belgeler" ve "geçici belgeler" şeklinde ifade edilmiştir. Bu sözlüklerin ilkinde efemera kavramı, "kısa ömürlü belge: genellikle örnek veya model olarak tutulan, geçici değere sahip resmi olmayan belgeler” (Karakaş, Rukancı ve Anameriç, 2009, s. 29); ikincisinde, "geçici belgeler: geçici olarak saklanan (belgeler)" (Üstün, 2011, s. 92, 126) olarak açıklanır. 
Koleksiyoncularınkinden, müzecilerinkinden, kütüphanecilerinkinden ve arşivcilerinkinden ayrı olmak üzere; başka meslekten olanların da efemerayı anlamlandırma çabaları vardır. Onlar çok daha başka yollarla ve "ayrıntı"dan hareketle efemera tanımı yapmaktadırlar. Örneğin; Fransız iktisat tarihçisi Fernand Braudel’e (1902-1985) göre efemera şöyle açıklanmaktadır: "Olaylar tarihin efemerasıdır; sahneden ateşböcekleri gibi geçerler, hemen karanlığa gömülürler, çoğu zaman unutulacak kadar bile değersenmezler. Ancak her bir olay, bazı karanlık köşeleri veya hatta tarihin geniş bir manzarasını aydınlatmak için bir katkıdır.” (Braudel, 1995, s. 901). Efemeranın bundan başka anlamlarda kullanıldığına işaret eden başka meslek mensupları da bulunmaktadır. Edebiyat bu alanlardan birisidir. Rasim Özdenören gibi bazı şairler, şiirlerinde efemeranın ne olduğu ile ilgili açıklamalar yapmaktadır. Şiiri efemera kabul eden şaire göre, şair, şiirinde ânı yakalamak peşindedir. Bu yüzden şiir salt ayrıntıdan oluşan ânların toplamıdır. Bu nedenle, "Uçup giden bir ânı yakalamak tekrarı olmayan bir yaşam parçasını yakalamak olur.”. Ayrıntıdan ibaret bir ânı yakalamak da "anlamlı bir yaşam bütünlüğü” ortaya çıkarmaktadır. İşte "Şiirdeki bu ayrıntı, bir bakıma meraklısı için bir efemera mesabesindedir." (Özdenören, 2015, ss. 6-7).

Bunlardan hareketle efemera için ortak bir tanıma ulaşmak imkânı maalesef yoktur. Ancak genel olarak bu bilgilerin efemera için "günlük yaşamın ikincil ve kısa süreli belgeleri” şeklindeki kısa ve genel geçer tanımın geçerliliği üzerinde durulabilir (CILIP, 2003, s. 12). Yukarıda verilen bilgilerden ancak sadece bir kısmı geçerli olabilecek ortak sonuçların dayanağı olabilir. Buna göre efemera için verilen tanımlardan efemera için şu ortak bilginin anlaşılması mümkündür: ${ }^{3}$

- Kisa süreli bir amaca özel ve düzensiz olarak üretilir,

- Kisa ömürlüdür ve devamları yoktur,

- Acil kurumsal bir eylemi gerektirmez,

- Biriktirilmek amaciyla üretilmez,

- Formatı değişkendir, -basılı, yazılı, görsel-işitsel ve elektronik olabilmektedir-,

- Resmi ve gayri resmi olabilir,

- Dosya bağı hiç olmamıştır,

- Dosya ilişkisi sonradan yok edilmiştir,

- Kurumla organik bağı kopartılmıştır,

- Genellikle bir faaliyetin parçası olmadıkları için karşı işlemi gerektirmez,

3 Bu gruplandırma; kısmen Somer ve Keskin (2012, s. 445) tarafından yapılmış olan çalışmaya dayandırılmıştır. 
- Ivır zıvır ürünler olarak görülüp küçümsenir,

- $\quad$-Bir kısmının- kaynak değerleri zamanla anlaşılır,

- Korunma nedeni genellikle sahip olduğu simgesel değerleridir -bu durum onların genellikle kişilerde toplanmasının nedeni olmuştur-,

- Görünüşü aldatıcıdır -değeri konusunda kararsız kalınabilir-,

- Gündelik yaşamın bölük pörçük (parçalar halindeki) dokümanlarıdır,

- Yararlılığı değişkendir,

- Bilgi kurumlarının (kütüphanecilik ve arşivcilik tekniği açısından) standart uygulama ilkelerine göre tasnif edil(e)mez,

- Birincil ya da ikincil kaynak değeri vardır,

- Dayanıksızdır.

Bu özelliklerin her birinin tek bir efemera belgesi üzerinde görülmesi söz konusu değildir. Yine bütün bu açıklamalardan anlaşılan, efemeranın üzerindeki bilginin kaydedilme şeklinin ve bilgisel değerinin; mesleki, bilimsel ve yönetimsel bakış açısıyla şekillendirilmeye çalışılmış olduğudur. Dolayısıyla bu bakış açısının arşivcilik, kütüphanecilik ve müzecilik mesleklerini hatta koleksiyoncuları ilgilendiren yönlere sahip olduğuna işaret etmek gerekir (Somer ve Keskin, 2012, s. 445).

\section{Arşivci Efemera Denilen "Şey"den Ne Anlar?}

Buraya kadar verilen bilgiler efemeranın özelliklerine dair bir açıklama yapmaya imkân vermektedir. Bu bilgiler efemeranın geçici/kurumsal bir etkinlik sürecinde üretilen materyal olduğuna, kısa süreli bir amaç için ve düzensiz olarak üretildiğine, genellikle kısa ömürlü olduğuna ve devamları olmadığına, acil kurumsal bir eylemi gerektirmediğine, biriktirilmek amaciyla üretilmediğine, formatının değişken olduğuna, bir faaliyetin -genellikle- bir parçası olmadıkları için karşı cevabı gerektirmediğine, önemsiz görülüp kaynak değerlerinin küçümsendiğine, simgesel değere sahip olduğuna, arşivsel değeri konusunda kararsız kalınabildiğine, seçimlerinde arşivcinin öznel kararının belirleyici olduğuna, gündelik yaşamın bölük pörçük parçaları olduğuna, bir bütünün parçası olmadığına, genellikle koleksiyoncular tarafından toplandığına, bilgi kurumlarının (kütüphanecilik ve arşivcilik tekniği açısından) standart uygulama ilkelerine göre tasnif edil(e)mediğine, -görünüşü aldatıcı olsa bile- kaynak değerine sahip bulunduğuna, dosya-fonksiyon ve kurumsal bir bağının bulunmadığına, var olan dosya ve kurumsal ilişkinin zamanla kopartıldığına, geçici, resmi ve gayrı resmi organizasyonlar/kurumlar tarafından üretilebildiklerine işaret etmektedir. 
Yukarıda efemera için verilen bilgilerden hareketle, arşivciyi ilgilendiren öncelikli ve temel hususun efemeranın kaynak değerinin tespit edilmesi olduğu ileri sürülebilir. Yani arşivci için bir materyali edinmenin temel gerekçesi bilimsel araştırmalara kaynaklık etme niteliği, kaynak olabileceği ihtimalidir. Ancak birçok arşiv kurumu, yasal olarak kendisine intikal etmesi genellikle mümkün olmayan belgelerin toplanmasında yetersiz kalmakta veya bu materyalin toplanması hususunda inisiyatif alınması akla bile gelmemektedir. Bu yüzden arşiv kurumları efemera türü belgelerin toplanması işini sahadan, inisiyatif kullanarak ve aktif bir şekilde gerçekleştirmek durumundadır.

Yine yukarıda verilen açıklamalar, efemeranın kurumsal bağı ve dosya ilişkisi olmadığına veya var olan ilişkinin kopartıldığına işaret etmektedir. Bunun nedeni ise ya dikkatsiz bir şekilde yürütülen arşiv çalışmalarıdır ya da sorumluluklarını samimi bir şekilde yerine getirmeyen kurum personelinin/arşivcinin kendilerine gelen belgelerin korunmasında gösterdikleri özensizliktir. Diğer yandan, protesto eylemleri ve yasal/yasal olmayan mitingler gibi geçici organizasyonlar tarafından üretilen efemeranın organik bağının belirsizliği ve bu tür organizasyonlar tarafından üretilen efemeranın anonim olma niteliği açıktır. Organizasyon niteliği olan bir yerde, -geleneksel belge üretim biçimine göre- bu organizasyonun yasal-resmi mensubu olanlar tarafından yürütüldüğü ve bu şekilde belgelerin üretilmesinin söz konusu olduğu açıktır. Ancak geçici organizasyonların etkinliğine katılan bireylerin organizasyonla "manevi" ilişkiden başka bir bağı yoktur. Bu da, bu organizasyonlar tarafindan üretilen belgelerin anonim özelliğini daha da belirgin hale getiren önemli bir unsurdur. Bununla birlikte, üretildikleri ilk zamanlarda kurumsal ve dosya bağları olan ancak artık bu bağ ilişkisinin olmadığı belgeler de söz konusudur. Bu durum, mevcut belgenin efemeral niteliğini uygulayıcılar açısından tereddütlü hale getirebilir. Bir zamanlar var olan ve sonradan yok edilen kurumsal ve dosya bağ ilişkisinin yeniden tesis edilmesinin imkânsızlığ 1 ve zorluğu bu konuda karar vermeyi kolaylaştıracak bir etken olarak değerlendirilebilir. Bu durumda arşivci, elindeki belgeyi efemera olarak nitelendirmelidir.

Hemen yukarıda belirtilen olumsuzluklara işaret eden pek çok örnek söz konusudur. Sahaflarda ve müzayede etkinliklerinde efemera olarak gruplandırılan pek çok belgenin durumu, belgenin üretim ilişkisinin zamanla bir nedenle yok edildiğini göstermektedir. Koleksiyoncular ve sahaflar ellerinde bulunan ve satılmak üzere farklı yollarla piyasaya sürülen pek çok resmi ve kurumsal faaliyetler sırasında üretilen farklı türdeki belgeleri aleni bir şekilde "efemera" adıyla satışa sunmaktadır. Bu tür belgelerin içeriklerine ve üretim yerlerine bakıldığında kurumsal bağlarının olduğu, resmi-özel bir kuruma ait olabildiği ve bir zamanlar kurumsal bir fonksiyonun yerine getirilmesi sırasında üretildikleri, bu nedenle de bir süre önce dosya bağlarının söz konusu olduğu görülür. Bununla birlikte kurumsal ve dosya bağı olmayan/ sonradan bir şekilde kopartılmış olan, bazılarının üretim tarihi belli olmayan bu belgelere arşivcinin nasıl bakması gerektiği önemli bir sorun olarak karşımızda durmaktadır. 
Yakın zamanlarda bir gazete için kaleme alınan bir köşe yazısında, özel bir arşivin parçası durumunda olan ve bir kısım Osmanlı dönemi -ferman ve berat gibi- belgelerin koleksiyoncular tarafından bazı yönleriyle tahrif edilerek daha yüksek meblağlara antika mezatlarında alıcı bulabildiği eleştirel bir bakış açısıyla ve alaycı bir dille okuyuculara duyurulmuştur. Yazıda verilen bilgiye göre; belgelerin satış değerinin yükseltilmesi için, "efemera" türünde koleksiyonluk belge toplayanların "ellerindeki ferman ve berat cinsinden eski evrakı müzayedeye koymadan önce "müzehhip"lere, yani tezhipçilere gönderip baştan aşağı" boyatmaktadırlar, hattatlara bazı ifadeler ekletmektedirler ve satışa öylece sunmaktadırlar (Bardakçı, 2018). ${ }^{4} \mathrm{Bu}$ işlemin koleksiyoncular tarafından kazanç getirici bulunduğu için tercih sebebi olduğu ve -bilinçli/ bilinçsiz- alıcılar tarafından -muhtemelen- toplumsal itibar kaygısıyla da rağbet bulduğu açıtır. Ancak böyle bir uygulamanın arşiv ve tarih bilimleri bakımında problem teşkil ettiğini bilmek gerekir. Yapılan işlem sonucunda ilgili belgenin bilgi değerine halel getirilmiş, bu nedenle kaynak değeri düşürülmüş -belki de yok edilmiş- ve belge itibarsızlaştırılmış olmaktadır. Dahası, koleksiyoncular ve antika/efemera meraklıları için yeni ilavelerle tercih ve itibar sebebi olan bir belge arşivci ve tarihçi için uzak durulması gereken değersiz bir belgeye dönüşmüş olur. En basit ifade ile bu belgeler, tarihçiler ve arşivciler için bilgi değeri sonradan eksiltilmiş ve bu sebeple de kıymetsiz ve problemli bulunur. Bu da, sonradan işlem görmüş bir belgenin değerinin ve efemera niteliğinin antika meraklıları, ticari kazanç ve toplumsal itibar peşinde koşanlar için devam ettiğini, ancak arşivciler için -kaynak değerine zarar verilmiş olması nedeniyle- artık ilgilenmenin -neredeyse- söz konusu olamayacağını ifade eden problemli bir duruma işaret etmektedir. Bu tür bir belgenin tarihçiler tarafından ilgi duyulacak yönünün -belki de tek yönünün- sadece tahrif işleminin bilimsel olarak açıklanmasıdır.

Sunulan az sayıda örnekten hareket ederek bile, efemeranın farklı meslekler için ortak bir tanımsal açıklamaya sahip olmadığını ifade etmek mümkündür. Diğer yandan, farklı meslekler tarafından ve genel sözlüklerde ve mesleki terminoloji sözlüklerinde verilen -bir kısmını yukarıda verdiğimiz- açıklamalar da bu sonucu açıkça ortaya koymaktadır. Bu da, içlerinde pek çok arşivcinin de olduğu ve efemeraya bir şekilde ilgi duyan geniş bir kitlenin efemeranın tanımı üzerinde genel bir mutabakat sağlamaktan uzak olduğuna işaret etmektedir (örneğin efemeraturk.com, 2018). Bu durum efemeranın en azından arşivciler için anlaşılır, karmaşıklıktan uzak ve araştırmacıların ilgi sahasına girdikleri için toplandıkları gibi temel argümanları ihtiva eden net bir tanıma ihtiyaç duyulduğunu göstermektedir (Somer ve Keskin, 2012, s. 445).

4 İçinde efemera türü belgelerin satışa sunulduğu bitpazarlarında bile artık bu ilgiyi farklı şekillerde görmek mümkündür. Günümüzde eski harfli efemera satın almak isteyenlerin talip oldukları materyalin içeriğini anlamak için bir uzmana başvurma ihtiyacında oldukları bilinmektedir. Bitpazarlarında bu ihtiyacı gidermeye yönelik hizmetlerin devreye sokulduğunu gösteren "Osmanlıca okunur" ibareli stantlar bunu teyit etmektedir (Dr. M. Fahri Furat, kişisel iletişim, 10 Mayıs 2018). 
Dikkati çeken temel hususlardan birisi efemeranın sonradan (ve özellikle de sahadan) “derlendiği”, bu yüzden söz konusu materyalin -geleneksel arşivcilik teorisinin bir gereği olarakarşiv birim ve kurumlarının doğrudan devir malzemesi olmadığıdır. Roberts (1993, s. 412), -bu konuya işaret ederken- bir arşivci için cevaplanması gereken en temel problemin, efemeranın arşiv malzemesi olarak dikkate alınıp alınmaması gerektiği şeklindeki soru olduğunu ifade eder. Ancak efemeranın -arşivlerin klasik görev sahasında olmadığı ve kurumsal faaliyetler sırasında üretilmiş olsalar bile doğal olarak biriken belge grubundan olmadığ 1 için- arşivcilik açısından dikkate alınması güçtür. Bununla birlikte efemera, -bir şekilde ihtiva ettiği bilgi değeri nedeniyle- bir arşivin birçok yönden faydalı bir parçası ve koleksiyonu olabilecek değere sahiptir.

Efemeranın ihtiva ettiği bilgisel değeri, tek nüsha olarak üretilenlerin yanı sıra çok sayıda üretilme durumları ve doğal yolla arşiv kurumlarının devir malzemesi olmaması aslında yeni bir tanımı gerekli kılmaktadır. Diğer yandan, Roberts tarafından efemera için verilen ve dört maddeden oluşan nitelik bu belgelerin arşivlerde toplanması için yeterli görünmemektedir. $\mathrm{Bu}$ durumda efemera için doğal yolla birikmemesi ve arşivlerin klasik devir konusuna muhatap olmaması hususlarına açıklık getiren yeni bir tanıma ihtiyaç vardır. Bu belgelerin diğer özelliklerinin yanı sıra hem bir kurumsal fonksiyonun parçası olarak üretilerek bir klasörün/dosyanın parçası olmuş, üretim zincirinden kopartılmış ve bağımsız bir unsur haline getirilmiş olabileceği hem de organik olarak üretilmeyebileceği söz konusudur. $\mathrm{Bu}$ tür belgelerin, parça halinde olması ya da sonradan/suni olarak oluşturulan bir koleksiyonun parçaları olabileceği, ancak nadiren (ve muhtemelen imkânsızlık mesabesinde olan büyük zorluklarla) dosya bağlarının kurulabileceği konusunu da gündeme getirir. Diğer yandan, tanımlarda yer alan 'geçici değere' sahip olma niteliğinin göz ardı edilmesi gerekir. Gerçek değerinin sonradan anlaşılması ise artık zaten itibar edilen bir durum değildir. Zira bu tür belgelerin bilgi değerinin sınırının olmadığı herkes tarafından takdir edilmektedir. Yani -önemli bir kısmı başlangıçta uzun süreli kullanım amacıyla üretilmemiş olsa da- efemeranın değeri geçici değildir. Geçici olana arşivci zaten itibar etmez, itibar etse bile araştırmacı tarafından bu türden belgeler itibar görmez, bu yüzden de bu belgelerin arşivlerde korunması için çaba gösterilmez. Araştırmalara delil teşkil etmeyecek bir belgenin arşivciler tarafından korunması söz konusu değildir. Buna gerekçe ise bir belgenin bilimsel araştırmalarda bir konunun aydınlatılmasına delil teşkil etmeleridir. Ancak efemeranın bilgisel değer takdirinin problem teşkil etmesi konusunda karşılaşılabilecek tek sorun arşivcinin öngörü kabiliyetine sahip olma(ma)sıdır. Belge koruma/değerlendirme teorilerinin güvenilirliğinin getirdiği özgüvenle hareket etmenin mümkün olabilirliği bir yana, bilimsel paradigmada meydana gelebilecek herhangi bir konu genişlemesinin arşivci için öznel bir koruma/değerlendirme stratejisi gerektireceği açıktır. Bu da, arşivcinin efemeranın bilgisel değer tespitini üç temel noktadan hareketle yapabileceğini gösterir: 
1. Geleneksel değerlendirme stratejisi.

2. Yeni bilimsel gelişmelerin hissettirdiği kaynak ihtiyacının karşılanması için esnek bir değerlendirme stratejisinin uygulanması.

3. Arşivcinin öznel yaklaşımını mümkün kılan bireysel çabası.

Bütün bunlar kısa bir efemera tanımının -en azından arşivciler için- mümkün olmadığını açıkça göstermektedir. Yine bütün bu verilen bilgi yeni ve uzun bir efemera tanımının şu şekilde olabileceğini net olarak ortaya koyar: Arşivsel efemera; genellikle çok sayıda baskısı yapılan ve dağıtılan ancak kitap, broşür ve dergi gibi (bazı durumlar hariç) kütüphane malzemesi dışında kalan, kısa süreli organizasyonlar sırasında kısa süreli bir amaç için ve düzensiz olarak üretilen, resmi ve gayrı resmi kurumlar tarafından üretilebilen, biriktirilmek amacıyla üretilmeyen, genellikle devamı olmayan, özel bir zamanda ve özgün bir amaç için üretilen, acil bir kurumsal eylemi gerektirmeyen, kurumsal bir bağı olmayan, fon bütünlüğünde olmayan, dosya bağı sonradan kopartıldığı ya da hiç olmadığ sonradan oluşturulmuş bir koleksiyon içinde parçalar halinde bulunabilen, bir bütünün parçası olmayan, birbirinden bağımsız parçalardan oluşan, standart arşiv sınıflandırma ilkeleri uygulan(a) mayan, genellikle yararlılığı göreceli ve simgesel değeri olan, birincil ve ikincil kaynak niteliği taşıyan, korunduğu kurum ve arşivin mükelleflerince ilgili arşive devredilmemiş olan, üzerine kayıtlı bulunduğu bilgi taşıyıcısının önemli olmadığı -basılı, çizili, resimli, sesli, görüntülü, hareketli, elektronik vs.- dayanıksız bir materyaldir. ${ }^{5}$

Yukarıda verilen bilgiler ve geliştirilen yeni tanım; efemeranın tanımına ilişkin sorunların genellikle efemeraya yüklenen mesleki içerikten ve yarar kaygısından kaynaklandığını göstermektedir. Bu yüzden bir arşivcinin bir kütüphaneciden, bir müzeciden ve bir koleksiyoncudan hatta bir tarihçinin, bir sanatçının ve bir edebiyatçının farklı bir efemera tanımı vardır. Mesleki ilgi ve yarar bakış açıları ise bu belge grubuna yönelik farklı tanımlayıcı bakışı açıklayan önemli bir unsurdur. Buna bağlı olarak arşivci tarafından yapılması gereken yeni tanımın mantıklı gerekçelerini aşağıdaki maddeler oluşturmaktadır: ${ }^{6}$

1. Kısa süreli organizasyonlar tarafından üretilme: Konunun arşivciler tarafından ve fazla sorun teşkil etmeyen yanlarından birini; -muhtemelen- resmi ve kurumsal bir kimlik taşımayan kısa süreli/anlık organizasyonlar (miting, protesto vs.) tarafından/ organizasyonlar sırasında üretilen belgeler oluşturmaktadır. Bu organizasyonlar tarafından üretilen ve organizasyon sonrasında sahipsiz/başıboş kalan belgelerin genellikle efemera olarak nitelendirilmesi mümkündür. Yasal izinle geçici olarak oluşturulan organizasyonlar tarafından düzenlenen belgelerin bir kısmının ilgili resmi

5 Bu tanım, kısmen daha önce yapılan bir çalışmaya (Somer ve Keskin, 2012, s. 446) dayandırılmıştır.

6 Bu bilgiler, kısmen Somer ve Keskin (2012, ss. 446-448) tarafından daha önce yapılan çalışmaya dayanmaktadır. 
makamlara sunulma durumu vardır. Bunların faaliyetle ilgili olarak planlamalara dâhil edilmesi, faaliyetin belgelenmesi amaciyla organizasyonu düzenleyen kurumun faaliyet dosyalarına yerleştirilmeleri ve ilgili resmi makamlara sunulan belgelerin söz konusu makamların ilgili dosyalarında tutulmaları söz konusudur. Bunların efemera olarak nitelendirilmesi mümkün değildir. Ancak kısa süreli organizasyonlar sırasında üretilen belgelerin bir kısmının resmi/kurumsal bir kimlik altında üretilmedikleri, bu yüzden kaynağın belirsizliği problemi vardır. Diğer bir ifade ile kısa süreli organizasyonlara katılan insanlar tarafından kendisini ifade etmek gibi gayelerle bireysel olarak düzenlenen ve etkinlik sırasında düzenlenen belgelerin (döviz, pankart, afiş vs.) ise doğrudan efemera olarak nitelendirilmesi söz konusudur. Örneğin; bir protesto eylemine ilişkin üretilen afiş, pankart, döviz türü belgeler genellikle herhangi bir kurum tarafından toplanıp koruma altına alınmazlar. Dahası herhangi bir kurumun bu tür örgütlenmeler tarafından üretilen belgeleri toplama gibi resmi bir yükümlülüğü pek çok ülkede yoktur. Ancak gündelik yaşamın bir parçası olarak kültürel değer taşımaları onların geleceğe bırakılmalarını gerektirir. Çünkü bu belgeler, insanların ne düşündükleri, kendilerini nasıl ve hangi kelimelerle ifade etmeye çalıştıkları gibi döneme ilişkin bilgiler içermektedir. Bu da, -kesinlikle- efemera denilen bu tür belgelerin arşivciler tarafindan bizzat sahadan toplanmasını gerekli kılar.

2. Kısa süreli bir amaç için üretilme: Efemeranın üretilmesine sebep olan etkenlerden birisi genellikle kısa süreli organizasyonlardır. Miting ve protesto gibi geçici organizasyonlara katılanlar bireysel olarak kendilerini ifade etmek üzere afiş, pankart ve döviz gibi belgeler üretirler. Bu tür belgelerin üretim kaynağının etkinlik sonrasında bilinmesi ise neredeyse imkânsızdır. Üretenlerin ise zaten hatırlanmak gibi bir endişesi yoktur. Arzu ettikleri tek şey, o an düşüncelerini, öfkelerini, taleplerini, şikâyetlerini dile getirmektir; bu yolla dikkate alınmaktır; bunu da, en kolay (pratik) ve hızlı bir şekilde genellikle anlık olarak düzenleyerek açtıkları/düzenledikleri belgelerle yapmaktadırlar. Sosyal medya, -yapılan paylaşımlar nedeniyle- bu tür organizasyonlarda kimlerin ne yaptı̆̆ının belirlenebileceği neredeyse tek kaynaktır.

3. Biriktirilmek amacıyla üretilmeme: Geçici ve kısa süreli organizasyonlar sırasında üretilen belgeler genellikle oluşturuldukları alanlara terk edilir, sahipsiz kalır, üreticileri tarafından biriktirilmez. Üreten kişilerin amacı da zaten ürettikleri belgeleri yanlarında geri götürmek değildir; aksine -belirtildiği üzere- kendilerini ifade etmek, -mümkün olduğunca- daha geniş kitlelere seslerini duyurmak, dikkat çekmek ve dikkate alınmaktır. $\mathrm{Bu}$ tür belgelerin toplanmasından sorumlu bir kurum olmaması da bu belgelerin genellikle üretildikleri yerlerde kendi kaderlerine terk edilmesine sebep olur.

4. Düzensiz olma ve devamı olmama: Efemera, genellikle devamı olmayan bir belge üretim tarzına sahiptir. Üretenlerin anlık psikolojileri ve -geçici- organizasyon karakteri 
de aynı şekilde süreklilik arz etmez. Sürekliliği olmayan organizasyonlarda üretilen belgeler ise düzensiz bir tarzda üretilir ve bunların arkası, yani devamlılığ yoktur.

5. Farklı formatlarda üretilme: Efemeranın şekil özellikleri, bilginin üzerine kaydedildiği taşıyıcı ve bilginin kayıt şekli genellikle çok değişkendir. Geleneksel olarak elle yazılabildikleri gibi basılı, sesli, resimli ve grafik şeklinde de olabilir. Ancak teknolojik gelişmenin getirdiği avantajlar sayesinde günümüzde elektronik ortam üzerinde üretilen efemera da söz konusudur.

6. Kurumsal bir eylemi gerektirmeme: Belgelerin genellikle kurumsal bir faaliyetin yerine getirilmesi sırasında üretildikleri bilinir. Bu bakımdan bir belge ya bir eylemin başlangıcını, ya devamını ya da sonuca kavuşturulduğunu gösterir. Ancak geçici organizasyonlar sırasında üretilen bir belge bir eylemin başlangıcını, devamını ve sonuca kavuşturulduğunu göstermez. Dahası, bu tür etkinlikler sırasında üretilen belgelerin bir makama hitaben düzenlenmesi ve gönderilmesi de söz konusu değildir. Bu yüzden, geçici organizasyonlar sırasında bireyler tarafından üretilen efemera için yeni bir belge üretme eylemi, yani cevabi bir yazı hazırlanması şeklinde bir karşı eylem söz konusu değildir. Bu da, efemeranın -belge üretmek anlamında- karşı tepkiyi gerektirmeyen bir özelliğinin olduğunu gösterir.

7. Resmi ve gayri resmi kurumlar tarafından üretilme: Efemeranın üretilmesine kaynaklık eden kurumlar hukuk nazarında resmi ve gayrı resmi statüde, yani özel hukuk gerçek ve tüzel kişisi ile kamu tüzel kişisi olabilir. Ancak bu tür kurumlar tarafından üretilen efemeranın üretildikleri yerden bir şekilde sonradan alıkonulmuş olmaları ve artık kaynaklarının tespit edilememesi gerekir. Aksi takdirde, kurumsal bağı tespit edilebilen ve yasal olmayan yollarla alıkonulmuş belgenin -pek dikkat edilmese de- üretim yerlerine iadesi gerekir.

8. Dosya bağının (hiç) olmaması: Bir belgenin dosya bağının olması ancak kurumsal bir eylem için üretilmelerine ve bir kuruma hitaben yazılmalarına bağlıdır. Buna karşın, efemeranın genellikle böyle bir özelliği yoktur. Yani geçici ve kısa süreli organizasyonlar sırasında genellikle bireyler tarafından üretilen bir belgenin bir dosya bağı olmaz. Bu belgelerin üretenler tarafından toplanmaması, konuya ilgi duyan başka kişi ve kurumlar tarafindan bizzat etkinlik alanlarından toplanması söz konusudur. $\mathrm{Bu}$ da, bu tür belgelerin bir kısmının dosya bağları olmadığını/dosya bağı olmaksızın üretildiklerini; bu durumun bu tür belgelerin doğrudan efemera olarak nitelendirilmesine imkân verdiğini göstermektedir.

9. Dosya bağının/ilişkisinin sonradan yok edilmesi: Belgeler kurumsal bir eylemin icrası sırasında üretildikten sonra aynı konuda üretilmiş dosyalar içerisinde kendine özel bir 
yer bulur. Arşiv belgesi dendiğinde zaten bir dosya ile organik bağ, dosya dendiğinde ise bir fonksiyonla ilişkilendirilme hali akla gelir. Kurumsal fonksiyonlar doğrultusunda üretilen dosyaların oluşturduğu seriler ise diğer serilerle birlikte kuruma ait bir fonu oluşturur. Kurum evrakının sahip olması gereken bu düzen, aynı zamanda kurum çalışanları tarafından yapılması gereken yasal yükümlülüğe dayanan bir iştir. Çünkü kurum çalışanları, üretilen bir belgenin daha sonra bir sebeple (kurumsal iş süreçlerinde, yani idari, yasal, mali sebeplerle) üreten kurum tarafından kullanılabileceğini iyi bilir. Ancak bazı belgeler -bir fonksiyonla ilişkili olarak üretildikleri halde- koruma veya uygulama hataları sebebiyle ait olduğu dosyadan/seriden/kurumdan uzaklaştırılmış olabilir. Sonradan ihtiyaç duyulan bir belgenin yetkili makamlara sunulması söz konusu olduğunda ise erişim beklentisinin karşılanması yasal bir sorumluluk halini alır. Ancak kurumlar tarafından üretilen belgelerin bir kısmının içinde bulunmaları gereken dosyalara görevlinin özensizliği nedeniyle yerleştirilmemesi, daha sonra -bir sebeple- bulundukları dosyalardan bilinçsizce ve kasten kopartılması söz konusu olabilmekte ve bir daha eski yerlerine yerleştirilmeyebilmektedir.

Diğer yandan, bir kısım efemeranın kurumsal faaliyetler sonucunda üretilmesi nedeniyle bir bilgi kaynağı olarak kurum dosyalarının asli unsuru olma ihtimali de düşünülebilir. Örneğin; broşür, ilan ve satış posteri gibi parçaların birer efemera oldukları varsayılabilir. Ancak bu tür belgeler, eğer kurumsal bir faaliyet neticesinde üretildilerse, üretilmelerine neden olan faaliyetle ilişkili dosyanın bir parçasını oluştururlar. $\mathrm{Bu}$ durum, söz konusu belgelerin birer efemera olarak değerlendirilmesini engeller ve doğal olarak belgeler ait oldukları dosyaların tamamlayıcı parçaları olarak kalmalıdır (Makepeace, 1985, s. 29). Bir faaliyet sonucunda üretilen ilan, broşür gibi belgelerin faaliyete ilişkin diğer belgelerle birlikte oluşturdukları bütünlük bozulmamalıdır. $\mathrm{Bu}$ tarzda oluşan bir bütünlüğün yok olması/yok edilmesi, öncelikle dosya bütünlüğünün bozulmasına, daha sonra materyalin bilgisel öneminin azalmasına ve sonra da delil olarak işlem görme niteliğine halel gelmesine hatta asıl kaynak değerinin yok olmasına yol açabilir. Kısacası, bir dosyanın parçası olan her bir belge kendi dosya bütünlüğü içinde değerlendirildiğinden, bu tür belgeler efemera olarak değer görmez. Kurumsal faaliyet sirasında üretilen ve ait olması gereken dosyasında bulunmayan bir belgenin -yeniden ait oldukları dosyalarına yerleştirilmedikleri sürece- efemera grubunda değerlendirilmesi gerekir. Bu durum; efemera olarak adlandırılan belge türünün dosya/fonksiyon bağının ya hiç olmadığını veya bir nedenle zaman içinde ilişkili olduğu dosya/fonksiyon bağından kopartıldığını gösterir. Bazı koleksiyoncularda ve sahaflarda -özellikle Osmanlı İmparatorluğu döneminde üretilen- bu türden belgelerin bulunduğu bilinmektedir. Burada yeniden şu kuralın hatırlanmasında fayda vardır: Efemera genellikle öteden beri sahadan tek tek toplanan bir belge grubuna verilen genel bir isimlendirmedir. 
10. Bir bütünün parçası olmama/bir işleme dayanak oluşturmama/bir işlem nedeniyle bir dosyanın parçası olmama: Dosya içindeki her belge dosyanın tekemmülü/ tamamlanması açısından büyük önemi haizdir. Yani dosya içerisindeki her belge dosyanın bütünselliği bakımından vazgeçilmez bir değere sahiptir. Bu durum, aynı zamanda dosya içerisindeki hiçbir parçanın dosyadan çıkartılamayacağını; dosyanın bütünlüklü yapısı içerisindeki herhangi bir parçanın alınamayacağını gösterir. Diğer yandan, bazı durumlarda bir kısım efemera, -başlangıçta herhangi bir dosya ilişkisi olmadığ1 halde- sonradan yürütülen bir işlem nedeniyle oluşturulan bir dosyanın sonradan parçası haline getirilebilmektedir. Örneğin; bir idari/hukuki bir işlem nedeniyle oluşturulan bir dosyanın işleme delil teşkil eden bir parçası olarak dosyaya kabul edilen efemera, dosyanın bir parçası olduktan sonra artık efemera olarak nitelendirilmez. $\mathrm{Bu}$ durum, efemeranın bütünsel bir yapısının olamayacağına işaret eder. Yani dosyadan bir parça kopartıldığında dosyanın bütünlüğü bozulur.

11. Kurumsal bağın kopmuş/kopartılmış olması: Kurumlar tarafından işlemler sırasında üretilen belgeler kurum dosyalarında ve kuruma ait/kurumla ilişkili bir depoda/ arşivde korunur. Genellikle her kurum için geçerli olan bu durum, bazı zamanlarda çalınma, bilinçli olarak kurum dışına çıkarma gibi farklı, genellikle de art niyet taşıyan nedenlerle kuruma ait bir depoda tutulmayabilmektedir. Bu da, bazı belgelerin sadece ait oldukları dosyadan değil aynı zamanda üretildikleri kurumun korumasından da kopartılmış olabileceğini, belgenin artık üretildiği kurumla olan organik ilişkisinin bozulduğunu/yok edildiğini gösterir. Bu tür belgelerin genellikle bir daha geri, yani eski yerine (kurumuna ve dosyasına) taşınması söz konusu olmaz. Dolayısıyla sonradan ait olduğu kişi ve kurumların malıymış gibi itibar görürler. Bu da, bu tür belgelerin bir efemera olarak nitelendirilmesine neden olur.

12. Fon bütünlüğünnde olmama: Arşiv fonları üretildikleri kurumların arşivlerinde/ oluşturuldukları şahıs-aile arşivlerinde ve ilgili kurumun yasal olarak mükellefi bulunduğu veya hiyerarşik olarak bağlı olduğu daha üst düzey arşiv kurumlarında korunurlar. Bu arşivler; dosya-seri bütünlüklerinin yanı sıra fon bütünlüklerinin de korunmuş olduğu arşivlerdir. Bu durum, genellikle kamu kurumları tarafindan oluşturulan arşivler için geçerli olduğu kadar özel arşivler için de geçerlidir. Ancak bazı arşivler, -fon bütünlüğü muhafaza edilmekle birlikte- üretildikleri kurum arşivlerinde, oluşturuldukları şahıs-aile arşivleri olarak ve kurumun ürettiği belgeleri hiyerarşik olarak devretmesi gereken daha üst düzey arşiv yapılarında muhafaza edilmeyebilmektedir. Ancak bu tarz uygulamalar daha çok özel arşivler için geçerlidir. Yani dosya-seri yapıları muhafaza edilen bazı özel arşivlerin özel arşiv sahibi tarafından fon bütünlügünde hiyerarşik bir ilişkisinin bulunmadığı arşivlere devredilmesi, bağıșlanması, satılması söz konusu olabilmektedir. Hiyerarşik bir ilişkisinin bulunmadığı ve fon bütünlüğü 
içerisinde başka arşivlere devredilen arşivlerin dosya-seri bütünlükleri muhafaza edildiği için bu arşiv içerisinde bulunan herhangi bir belgenin de efemera sayılması mümkün değildir. Ancak bu türden yapıların içerisinde üreten/oluşturan kurum/şahıs tarafından faaliyetler/ilişkiler sırasında üretilmeyen ve yalnızca kurum/şahıs ilgisi nedeniyle arşive giren belgelerin de bulunabileceği dikkatlerden uzak tutulmamalıdır. Arşivlerin içinde bulunan ancak sahibi tarafından bir faaliyet/ilgi nedeniyle üretilmeyen belgelerin efemera olarak nitelendirilmesi gerekir.

13. Konusal bağlama sahip olmama: Arşivcinin düzenleme çalışmasında esas olan, organik bir düzen içinde dosyaların/serilerin arşive kabulüdür. Mesleki teori, yasal prosedürler ve uygulama gelenekleri arşivsel çalışmaların bu yönüyle hassas şekilde ilgilenir. Yani arşivci, bir belgenin yönetimsel bir faaliyet sırasında üretilmesi nedeniyle, ilgili belgenin faaliyet alanına bağlı oluşturulmuş dosyasına -bütünün parçası olması nedeniyle- koyulmasını kural olarak benimser. Ancak efemera için böyle bir durum söz konusu değildir. Arşivcinin efemerayı genellikle sonradan oluşturulan konusal bir bağlamla veya ilgili belgenin kayıtlı bulunduğu bilgi taşıyıcısı türüne bağlı olarak ele alması gerekir. Bunun nedeni, efemeranın kurumsal bir devir süreciyle devralınmamasıdır. Saha taraması usulüyle ve aktif yaklaşımla efemeranın toplanması böyle bir bakış açısını zorunlu kılar. Bu durum, diğer mesleklerin efemera tanımından arşivciliği ayrılan bir noktadır. Yani efemera türü belgelerin düzenlenmesinde diğer bilgi kurumlarından farklı bir yaklaşım sergilenir. Bu tür bir düzenleme yöntemi, arşivcilikte sadece nasıl bir düzen içinde oldukları kesinlikle belirlenemeyen özel arşivler için uygulanmaktadır.

14. Kaynak değerine sahip olma: Yapılan tanımlarda dikkati çeken önemli bir husus, efemeranın "önemsiz" ve "kısa ömürlü” belgeler oldukları şeklindeki bakış açısıdır. $\mathrm{Bu}$ bakış acısı, efemera ile ilgilenenler tarafından ortaya konulmuş karakteristik ve geleneksel bir yaklaşımdır. Daha doğrusu bir efemeraya sahipliği sağlayan şey, üretenlerin ona değer vermeyerek önemsiz bulmaları, sahip çıkmamaları ve kendi arşivlerinde muhafaza etmemelerinden kaynaklanmaktadır. Onu toplayanlar ise ya maddi-manevi kazanç ya da kaynak değeri nedeniyle önemli bulmaktadır. Diğer yandan arşivci için önemsiz olanın bir değeri yoktur; önemsiz olan imha edilir, arşivlerde gereksiz ve fazladan yer işgal etmesi ve araştırmacının araştırma süresinin içeriği zayıf belgelerden oluşan kalabalık materyal ile israf edilmesi önlenmiş olur. Araştırmalara kaynak olma değeri taşıyanların ise önemsiz olarak nitelendirilmesi anlamsızdır. Arşivci için önemli olan nokta efemeranın bilgisel değeridir. Efemeranın bilgisel değerinin anlaşılması için belge içeriğinin, form yapısının, içerdiği bilginin, yazı tarzının, baskı türünün, tasarımının, bilgi taşıyıcısının özelliklerinin vs. iyi anlaşılması gerekir. Belirtilen bu değer alanları bakımından hemen her tarihsel izin bir kaynak değeri 
bulunmaktadır. Üstelik bu durum efemeranın -duruma göre- birincil ve ikincil kaynak değerine işaret eder. Ancak arşivcinin iki zor karar arasında kalması bu bakımdan oldukça mümkündür: 1) İmha etmek veya 2) muhafaza etmek. Yani -imha teorisinin bir gereği olarak- bilgi değeri düşük ve daha konsantre belgelerde içeriğinin zaten bulunduğu gerekçesiyle imha uygulamasına yasal olarak yetkili olan arşivci bu noktada kararsız kalabilir. Bu önemli bir risktir. Burada temel kriter, gündelik yaşama ilişkin farklı ayrıntıların bulunduğu efemeranın arşive kabul edilmesi olmalıdır.

15. Simgesel değere sahip olma: Efemeranın korunma nedeni, onun genellikle kişilerde toplanmasına neden olan özelliğidir. Bu özellik, onun kaynak değerinin de ötesindedir. Yani efemeranın korunma nedeni genellikle sahip olduğu simgesel değeridir. $\mathrm{Bu}$ simgesel değer, kişilerin ve kurumların özellikle kendi geçmişleriyle ilgili buldukları, hobi konularıyla uyumlu gördükleri, mesleki ilgi gibi nedenlerle önemsedikleri için anlam bulmaktadır. Kişilerin ve kurumların geçmişinde, anılarında, hobilerinde karşılığı olan bir efemeranın simgesel bir değeri vardır. Bu yüzden kişiler ve kurumların bir kısmı efemerayı toplamak eğiliminde olur. Arşivciler, gerektiğinde ilgi duyanlara sunmak üzere bu simgesel değere sahip efemerayı geleceğe taşımak durumundadır.

16. Kaynak değerinin göreceli olması: Efemeranın kaynak değeri görecelidir. Görünüşü ilk bakışta aldatıcı olabilir ve kaynak değerini hissettirmez. Bu durum, arşivciyi efemera toplaması konusunda kararsızlığa davet eder. Bu yüzden arşivci, efemeranın kaynak değeri konusunda mesleki birikiminin yanı sıra kişisel becerilerine ve araştırma konularının hâlihazırda gerektirdiği ve gelecekte gerektireceği kaynak ihtiyacı konusundaki birikimine ve öngörüsüne güvenir.

17. Yararlılığın değişken olması: Her arşiv belgesi gibi efemera da bilimsel araştırmalar bakımından değişken kaynak değerine ve bilimsel yararlılığa sahiptir. Ancak bu değişkenlik, efemeranın toplanmasının önünde bir engel değildir. Kaynaklık değeri bir şekilde belirlenmiş olan ancak araştırmacılar tarafından hiç kullanılmayan bir efemeranın günün birinde bir araştırmaya temel olma ihtimali -diğer kaynak türlerinde olduğu gibi- her zaman vardır. Bu sebeple, bir kaynağın araştırmalarda yaygın kullanılması her zaman beklenmemelidir. Böyle bir beklenti olursa yanlış uygulamaların hayata geçirilmesi kaçınılmaz olur. Tarihi bir kaynak araştırmacılar tarafından uzun yıllar boyunca bazen hiç kullanılmayabilir. Bu durum, bir araştırmacının veya yeni bir bakış açısının söz konusu belgeye yönelmesine kadar devam eder.

18. Birbirinden bağımsız parçalardan oluşma: Efemera genellikle gündelik yaşamın bölük pörçük ve parçalar halindeki dokümanlardır. Bu parça halindeki dokümanlar araştırmacının zihnindeki kurguyla, araştırma becerileriyle ve mesleki birikimiyle birleştiğinde efemeranın asıl kaynak değeri ortaya çıkar. Bundan da anlaşılacağı üzere, 
efemera parçalarının araştırmalara kaynaklık etmesi araştırmacının kendisine bağlıdır. Anlamsız gibi görünen ve zaten hammadde durumundaki efemeranın önem kazanması becerikli araştırmacıların eliyle mümkündür. Bu durumu göz önünde bulundurması gereken arşivci ise bazı zamanlar kaynak değerini fark etmekte karşı karşıya kaldığı güçlüğü arşivlerden yararlanan araştırmacılardan destek alarak aşmayı denemelidir.

19. Düzenleme yöntemlerinde değişkenlik: Efemeranın yönetilmesi uygulamalarında genellikle "gıyaben değerlendirme", başka bir ifade ile "suni"/“yapay” bir düzenleme eğilimi hâkimdir. Efemera ister tek sayfa halinde isterse birkaç sayfalı ve kısa/uzun metinli dokumanlar şeklinde olsun, sahip olunan belgelerin arşivcilik uygulamalarında konusal/fonksiyonel olarak ilişkili bulunan dosyalarıyla eşleştirilmesi eğilimi vardır. Genel kabul gören mesleki uygulama ilkeleri de bunun aksini müsaade etmez. Bu da açıkça göstermektedir ki, arşivciler tarafından efemeranın farklı bir kaynak türü olarak kabul edilmesi için kimliği tam anlaşıl(a)mayan geçici bir yapı tarafından üretilmesi, kaynağından kopartılması, ait olduğu seriden alınması, dosya bütünlüğünün bozulması ve bütünlüğün yeniden inşa edil(e)memesi gerekir. Bu tür özelliklerin varlığı kesin olarak tespit edilirse, bir grup efemera belge için uygun bir konusal çerçeveye sahip yeni bir dosya bütünlüğünün oluşturulması mümkün hale gelir. Bilgi içeriğgine bağlı olarak konusal bütünlüğün hiçbir şekilde oluşturulamaması halinde ise alınabilecek genellikle iki karar vardır: 1) Sahip olunan efemeranın türler bakımından (türdeşleriyle birlikte) gruplandırılması, 2) efemeranın taşıyıcı malzeme bakımından gruplandırılması.

20. Korunduğu arşivin organik olarak bağlantılı olduğu bir yapı tarafından üretilmemiş olma/korunduğu arşivin doğal devir malzemesi olmama: Belgeler dosya, seri ve fon bütünlüklerinde arşivlerde muhafaza altına alınırlar. Ancak efemeranın böyle bir özelliği söz konusu değildir. Bu, efemeranın önemli bir diğer özelliğini oluşturur. Yani efemeranın üretildiği kurumla üretime dayalı organik bağının kopuk olması gerekir. Aksi takdirde, ilgili belgenin efemera sayılması söz konusu değildir. Bu da, efemeranın korunduğu arşivin doğal parçası olmadığını, sonradan ve farklı devir/toplama/derleme politikaları nedeniyle bulunduklarını, bu yolla arşive kazandırıldıklarını gösterir.

21. Dayanıksız olma: Dayanıksız olma hali, her arşiv belgesi için geçerli olabilecek bir özelliktir. Bu yüzden kurumsal yazışmalarda kullanılan belgelerin belli kalite standartlarına uygun üretilmiş olmaları beklenir. Dayanıksız olma hali diğer belgelere göre efemera için daha fazla söz konusudur. Efemeral belgeler, üretilme nedenleri ve üretildikleri yer/ortam dolayısıyla genellikle dayanıksız malzemeden üretilmektedir. Geçici organizasyonların yetkili organları tarafından üretilen aktiviteye ilişkin belgelerin genellikle oldukça kaliteli baskılar olmasına karşın, bu organizasyonlara katılanlar tarafından organizasyon esnasında üretilen belgeler oldukça kalitesizdir. Ayrıca kalitesiz yazı araç-gereçleriyle yazılan ve geçici organizasyon aktiviteleri sırasında üretilen ve 
-kalite ve fiziki boyut bakımlarından- bir standarttan yoksun olan bir kısım efemeranın beklendiği kadar uzun ömürlü olmayabileceği hatırdan uzak tutulmamalıdır. Bu yüzden, efemera edinen kişi ve kurumlar onun bu özelliğini bilerek koruma önlemi almalıdır.

Bütün bunlar aşağıdaki gibi bir tablo halinde de gösterilebilir:

Tablo 1. Bir belgenin efemera olarak değerlendirilmesinin şartları

\begin{tabular}{|c|c|c|}
\hline 1 & Kısa sureli organizasyonlar tarafından üretilme & $\checkmark$ \\
\hline 2 & Kısa süreli bir amaç için üretilme & $\checkmark$ \\
\hline 3 & Biriktirilmek amaciyla üretilmeme & $\checkmark$ \\
\hline 4 & Düzensiz olma ve devamı olmama & $\checkmark$ \\
\hline 5 & Farklı formatlarda üretilme & $\checkmark$ \\
\hline 6 & Kurumsal bir eylemi gerektirmeme & $\checkmark$ \\
\hline 7 & Resmi ve gayri resmi kurumlar tarafından üretilme & $\checkmark$ \\
\hline 8 & Dosya bağının (hiç) olmaması & $\checkmark$ \\
\hline 9 & Dosya bağının/ilişkisinin sonradan yok edilmesi & $\checkmark$ \\
\hline 10 & $\begin{array}{l}\text { Bir bütünün parçası olmama/bir işleme dayanak oluşturmama/bir işlem nedeniyle dosyanın } \\
\text { parçası olmama }\end{array}$ & $\checkmark$ \\
\hline 11 & Kurumsal bağın kopmuş/kopartılmış olması & $\checkmark$ \\
\hline 12 & Fon bütünlüğünde olmama & $\checkmark$ \\
\hline 13 & Konusal bağlama sahip olmama & $\checkmark$ \\
\hline 14 & Kaynak değerine sahip olma & $\checkmark$ \\
\hline 15 & Simgesel değere sahip olma & $\checkmark$ \\
\hline 16 & Kaynak değerinin göreceli olması & $\checkmark$ \\
\hline 17 & Yararlılığın değișken olması & $\checkmark$ \\
\hline 18 & Birbirinden bağımsız parçalardan oluşma & $\checkmark$ \\
\hline 19 & Düzenleme yöntemlerinde değişkenlik & $\checkmark$ \\
\hline 20 & $\begin{array}{l}\text { Korunduğu arşivin organik olarak bağlantılı olduğu bir yapı tarafindan üretilmemiş olma / } \\
\text { Korunduğu arşivin doğal devir malzemesi olmama }\end{array}$ & $\checkmark$ \\
\hline 21 & Dayanıksız olma & $\checkmark$ \\
\hline
\end{tabular}

\section{SONUÇ}

16. yüzyılda toplamaya konu olan ve 20. yüzyılın ikinci yarısından itibaren araştırmacılar tarafından kaynak olarak kullanılmaya başlanan efemeranın, farklı meslek gruplarınca farklı tarifleri yapılmıştır. Bu bakımdan efemera; koleksiyoncuların, müzecilerin, kütüphanecilerin ve arşivcilerin ilgi alanına girmiş ve efemeranın bu meslek gruplarının mensupları tarafından çeşitli tanımları ortaya konulmuştur. Bu tanımların ilgili meslek üyelerinin mesleki birikimleri, kurumsal amaçları ve ihtiyaçları ile şekillendiği dikkat çekicidir. 
Efemera, ilgilileri tarafindan genellikle sahadan tek tek derlenen ve sahaflardan ve müzayede etkinliklerinden satın alınarak toplanabilen bir belge grubuna verilen genel bir addır. Hangi kişi/ kurum tarafından üretilirse üretilsin, efemeranın özellikleri arasında şu önemli hususlar vardır: 1) Efemeranın dosya ve fonksiyon bağ yoktur, 2) bu bağ sonradan (bir nedenle) kopartılmıştır, 3) kimliği belirsiz bir kaynak tarafından üretilmiştir, 4) üretenin kimliği muhtemelen sonradan belirsiz hale gelmiştir, 5) -üretici kaynak bilinse bile- üreten kurumun aidiyetinde/mülkiyetinde değildir. Bütün bunlar, efemeranın hangi kuruma ait olması gerektiği ile ilgili derin bir belirsizliği beraberinde getirmiştir. Bu belirsizlik müze kurumları açısından aslında yok gibidir. Obje ağırlıklı teşhir malzemesi üzerinde durmaları, yani nesnelerin yapısındaki fiziki vs. farklılığın daha belirgin olması, arşiv ve kütüphane kurumlarına göre müze kurumları için sınır çizmeyi daha mümkün hale getirir. Ancak söz konusu arşiv ve kütüphane kurumları olunca, efemeranın her iki kurum tarafından da toplanabileceği düşünülebilir. Uygulamada da fiilen durum bu şekilde sürmektedir.

Arşivciler, arşivlerin edinebileceği efemeranın kurumsal bir fonksiyona bağlı olarak üretilmiş ve faaliyete bağlı bir dosyanın parçası olmaması gerektiğini bilirler. Bunlar haricinde kalan belgelerin efemera olduğu neredeyse kesindir ve -eğer bilgisel bir değere sahipse- arşivlere kazandırılmalarında bir sakınca görülmez. Bu nedenle efemera arşivciler için özellikle sahadan edinilebilecek bir belge grubudur. Diğer yandan efemera, bir koleksiyonun içinde ancak o koleksiyonu üreten tarafından bir resmi veya gayrı resmi bir faaliyet sonucunda üretilmiş olmamalıdır. Yani koleksiyon sahibi, efemerayı sahadan toplamış olmalıdır. Bu da, efemeranın koleksiyonerin faaliyeti neticesinde üretilmediğini ve faaliyetleri neticesinde kendisine gelen bir belge grubu içinde olmadığını göstermektedir.

Son olarak "bir arşivci, neyi efemera olarak niteler?” sorusuna cevap aranmalıdır. Bu sorunun cevabını, efemeranın arşivsel nitelikli tanımlarda geçen özelliklerinde aramak gerekir. Efemeranın arşivsel nitelikli tanımlarda belirtilen özellikleri şu şekildedir: Arşivsel efemera; genellikle çok sayıda baskısı yapılan ve dağıtılan ancak kitap, broşür ve dergi gibi (bazı durumlar hariç) kütüphane malzemesi dışında kalan, kısa süreli organizasyonlar sırasında kısa süreli bir amaç için ve düzensiz olarak üretilen, resmi ve gayrı resmi kurumlar tarafindan üretilebilen, biriktirilmek amacıyla üretilmeyen, genellikle devamı olmayan, özel bir zamanda ve özgün bir amaç için üretilen, acil bir kurumsal eylemi gerektirmeyen, kurumsal bir bağı olmayan, fon bütünlüğünde olmayan, dosya bağı sonradan kopartıldığı ya da hiç olmadığı için parça halinde sahadan derlenen ve sonradan oluşturulmuş bir koleksiyon içinde parçalar halinde bulunabilen, bir bütünün parçası olmayan, birbirinden bağımsız parçalardan oluşan, standart arşiv sınıflandırma ilkeleri uygulan(a)mayan, yararlılığı genellikle göreceli ve simgesel değeri olan, birincil ve ikincil kaynak niteliği taşıyan, korunduğu arşivin mükelleflerince ilgili arşive devredilmemiş olan, üzerine kayıtlı bulunduğu bilgi taşıyıcısının önemli olmadığı -basılı, çizili, resimli, sesli, görüntülü, hareketli, elektronik vs.- dayanıksız bir materyaldir. Bütün bu bilgiler, efemeranın bilgi taşıyıcısı olarak geniş bir eksende değerlendirilebileceğini, üretim 
ilişkisinin ya hiç olmadığını ya da zamanla üretim ilişkisinin koptuğunu ve genellikle kısa süreli organizasyonlar tarafından üretildiklerini açıkça göstermektedir.

Hakem Değerlendirmesi: Dış bağımsız.

Çıkar Çatışması: Yazar çıkar çatışması bildirmemiştir.

Finansal Destek: Yazar bu çalıșma için finansal destek almadı̆̆ını beyan etmiştir.

Peer-review: Externally peer-reviewed.

Conflict of Interest: The author has no conflict of interest to declare.

Grant Support: The author declared that this study has received no financial support.

\section{Kaynakça/References}

Acland, G. (1993). Glossary. Judith Ellis (Ed.), Keeping archives (2.bs.), (s. 458-481) içinde. Port Melbourne: D. W. Thorpe and Society of Australian Archivists.

Acun, F. (2011). Görselden tarih yazmak. Vahdettin Engin ve Ahmet Şimşek (Ed.), Türkiye'de tarih yazımı (s. 423-434) içinde. İstanbul: Yeditepe.

Ataman, B. K. (Türkçeye çeviren ve genişleten). (1995). Arşivcilik terimleri sözlüğü. İstanbul: Librairie de Péra.

Atlansoy, K. (1997). Edebî metinlerin tarih kaynağı olarak değeri. Mübahat S. Kütükoğlu (Ed.), Tarih Boyunca Türk Tarihinin Kaynaklarl Semineri (6-7 Haziran 1996) Bildiriler (s. 15-25) içinde. İstanbul: İstanbul Üniversitesi Edebiyat Fakültesi

Bardakçı, M. (2018, 19 Şubat). Bir tarihî belge katliamı. Haber Türk Gazetesi. Erişim adresi: http://www. haberturk.com/yazarlar/murat-bardakci/1843404-bir-tarihi-belge-katliami

Bradsher, J.G. ve Ambacher, B.I. (1992). Archival sampling: A method of appraisal and a means of retention. Mid-Atlantic Regional Archives Conference, Technical Leaflet Series, 8 (1992), 1. Erişim adresi: http:// www.marac.info/assets/documents/marac_technical_leaflet_8.pdf

Braudel, F. (1995). The mediterranean and the mediterranean world in the age of Philip II. California: University of California Press.

Burant, J. (1995). Ephemera, archives, and another view of history. Archivaria, 40, 189-198

Carr, E.H. (1961). What is history? London: Macmillan.

Carr, E.H. (1980). Tarih nedir? (Misket Gizem Gürtürk, Çev.). İstanbul: Birikim Yayınları.

Chartered Institute of Library and Information Professionals (CILIP). (2003). Ephemera: The stuff of history. Report of the working party on ephemera. Thatcham: Print Apple.

Clark, K. (1962). The making of Victorian England. Cambridge: Mass.: Harvard University Press.

Coles, L. (1988). Other archival holdings: A manual for small archives. Vancouver: Archives Association of British Columbia.

de Beaumont, S. (2010). The ephemera society. Erişim adresi: http://www.ephemerasociety.org.uk/articles/ ephsoc.html

Dearstyne, B. W. (2001). Arşivsel girişim: Modern arşivcilik ilkeleri, uygulamaları ve yönetim teknikleri (M. Akbulut ve A. O. İcimsoy, Çev.). İstanbul: (y.y.). (Orijinali 1992’de yayımlanmıştır). 
Efemeraturk. (2018). Erişim adresi: https://www.efemeraturk.com/ adresinden erişildi.

Ephemera. (2011). The Oxford English dictionary online. Erişim adresi: http://oxforddictionaries.com/ definition/ephemera

Ephemera. (2011). Online etymology dictionary içinde. Erişim adresi: http://www.etymonline.com/index. php?term=ephemera

Furat, M.F. (2014). Ottoman prisoners of war in Kharkiv region and Valki incident. Natalia Starostina (Ed.), Memory and mythology modern war and construction of historical memory, 1775-2000 (s. 251-278) içinde. Bethesda: Academica Press.

Göncüoğlu, S.F. (2010). Üçü bir arada olması gereken ilk arşivleme yöntemi; fotoğraf, efemera ve sözlü tarih çalışması. Kent Hafiza Merkezleri: Kent Kütüphaneleri, Kent Arşivleri ve Kent Müzeleri Sempozyumu -Bildiriler- (s. 327-355) içinde. Kayseri: Detay.

Güler, H. (2011, 9 Eylül). 10,1 milyar dolarlık Uzan davasını, Brad Pitt'in rol alacağı film gibi kazandık. Hürriyet Gazetesi, s. 8.

John Johnson Collection Exhibition. (2001). The ephemera of trade. Bodleian Library, University of Oxford. Erişim adresi: http://www.bodley.ox.ac.uk/johnson/exhibition

Karakaş, H. S., Rukanc1, F. ve Anameriç, F. (2009). Belge yönetimi ve arşiv terimleri sözlüğü. Ankara: Devlet Arşivleri Genel Müdürlüğü.

Kepley, D. (1984). Sampling in archives. American Archivist, 47, 125-130.

Keskin, İ. (2014). Arşivlerin ĕgitim ve kültür hizmetleri. İstanbul: Türk Edebiyatı Vakfı.

Keskin, İ. ve Somer, N. (2012). Efemera koleksiyonu oluşturmada arşivcinin rolü. Özgür Külcü, Tolga Çakmak ve Nevzat Özel (Yay. Haz.). Prof. Dr. Gülbün Baydur armağanı içinde (s. 35-41). Ankara: Hacettepe Üniversitesi, Bilgi ve Belge Yönetimi Bölümü.

Keskin, İ. ve Somer, N. (2013).Efemeranın bir bilgi kaynağı olarak değerlendirilmesi. Feridun M. Emecen, İshak Keskin ve Ali Ahmetbeyoğlu (Yay. Haz.). Osmanlı'nın İzinde. Prof. Dr. Mehmet İpşirli armă̆anı içinde (s. 205-217), c. 2. İstanbul: TİMAŞ.

Ketelaar, E. (2007). Moniments and monuments: the dawn of archives as cultural patrimony. Archival Science, $7 / 4,343-357$.

Ketelaar, E. (2009). The genealogical Gaze: family identities and family archives in the fourteenth to seventeenth centuries. Libraries \& The Cultural Record, 44/1, 9-28.

Kyvig, D.E. ve Marty, M.A. (2000). Yanıbaşımızdaki tarih (Nalan Özsoy, Çev.). İstanbul: Tarih Vakfı Yurt Yayınlar1.

Launder, M. (2002). Saving printed ephemera: Setting priorities in preserving evidence of the everyday. Current Studies in Librarianship, 26(1/2), 67-68.

Makepeace, C. E. (1985). Ephemera: A book on its collection, conservation and use. Brookfield Vt. U.S.A.: Gower.

Menne-Haritz, A. (1999). Schlüsselbegriffe der archivterminologie (2. bs.). Marburg: Veröffentlichungen der Archivschule Marburg - Institut für Archivwissenschaft.

National Library of Australia. (2011). Ephemera. Erişim adresi: http://www.nla.gov.au/what-we-collect/ephemera

Organ, M. (1987). Ephemera in archives: What to do? (a possible solution from the University of New South Wales Archives). Archives and Manuscripts, 15, 105-118. 
Özdenören, R. (2015). Şiir bir efemera materyalidir. Hece, 226, 6-7.

Pamuk, S. (2017). Arşivsel örnekleme yöntemlerinin arşiv serileri/sınıfları üzerinde uygulanması. Bilgi ve Belge Araştırmaları Dergisi. 8, 1-41.

Rickards, M. (1977). This is ephemera: Collecting printed throwaways. Brattleboro: Gossamer Press.

Rickards, M. (2000). The encyclopaedia of ephemera: A guide to the fragmentary documents of everyday life for the collector, curator, and historian. London: The British Library; New York: Routledge. Erişim adresi : http://www.amazon.com/Encyclopedia-Ephemera-Fragmentary-Documents-Collector/dp/0415926483

Roberts, D. (1993). Managing records in special formats. J. Ellis (Ed.), Keeping archives (2. bs.), (s. 385-427) içinde. Port Melbourne: D. W. Thorpe and Society of Australian Archivists.

Sanger, G. (1926). Seventy years a showman (2nd ed.). New York: E. P. Dutton \& Co., Inc.

Schellenberg, T.R. (1985). Principles of archival appraisal. Peter Walne (Ed.), Modern archives administration and records management. A RAMP reader (s. 269-279) içinde. Paris: UNESCO.

Schellenberg, T.R. (2008). Arşivsel değerlendirme ilkeleri (İlhan Bozan, Çev.). İshak Keskin (Ed.), Arşivcilik metinleri (s. 55-70) içinde. İstanbul: Yeditepe.

Stone, R. (1998). Junk mail: Printed ephemera and preservation of the everyday. Journal of Australian Studies, 22(58), 99-106.

Taylor, M.J. (2002). I'll be your mirror, reflect what you are: Postmodern documentation and the Downtown New York scene from 1975 to the present. RBM: A Journal of Rare Books, Manuscripts, and Cultural Heritage, 3(1), 32-52.

Tosh, J. (1997). Tarihin peşinde. Modern tarih çalışmasında hedefler yöntemler ve yeni doğrultular (Özden Arıkan, Çev.). İstanbul: Tarih Vakfı Yurt Yayınları.

Üstün, A. (2011). Enformasyon bilimi ve teknolojisi kavramlar sözlüğü (Almanca-Türkçe / Türkçe-Almanca). İstanbul: Elit Kültür.

Walne, P. (Ed.). (1984). Dictionary of archival terminology. München: New York: K.G. Saur.

Young, T. G. (2003). Evidence: Towards a library definition of ephemera. RBM: A Journal of Rare Books, Manuscripts, and Cultural Heritage, 4(1), 11-26. 